\title{
Analysis of the vertical structure and size distribution of dust aerosols over the semi-arid region of the Loess Plateau in China
}

B. Zhou, L. Zhang, X. Cao, X. Li, J. Huang, J. Shi, and J. Bi

Key Laboratory for Semi-Arid Climate Change of the Ministry of Education, College of Atmospheric Sciences, Lanzhou University, Lanzhou, 730000, China

Received: 26 December 2011 - Accepted: 15 February 2012 - Published: 27 February 2012 Correspondence to: L. Zhang (zhanglei@|zu.edu.cn)

Published by Copernicus Publications on behalf of the European Geosciences Union.

Analysis of the vertical structure and size distribution of dust aerosols

B. Zhou et al.

Title Page

Abstract

Conclusions

Tables

14

$\triangleleft$

Back

Full Screen / Esc

Printer-friendly Version

Interactive Discussion 


\section{Abstract}

Using measurements of dual-wavelength polarisation lidar, particle sizer, and nephelometer from the Semi-Arid Climate and Environment Observatory of Lanzhou University (SACOL), the properties of dust aerosol extinction coefficient, optical depth, 5 depolarisation ratio, colour ratio, size distribution, and concentration over the semi-arid region of the Loess Plateau in north-western China are analysed in a case study of dust storms from 16-18 March 2010. The results show that dust aerosols are distributed mostly within the lower layer (below $3.0 \mathrm{~km}$ ), with the dust aerosol extinction coefficient ranging from 0.1 to $1.0 \mathrm{~km}^{-1}$. The average optical depth and depolarisa10 tion ratio are near 0.6 and 0.3 , respectively, while the colour ratio ranges from 0.8 to 1.0. The mass size distribution of dust aerosols has two peaks at $0.7 \mu \mathrm{m}$ and $5.0 \mu \mathrm{m}$, respectively, while the number size distribution of dust aerosols is log-normal with a maximum near $0.8 \mu \mathrm{m}$. Particles in the fine mode $(r \leq 2.5 \mu \mathrm{m})$ are predominant in the dust storm. Their number concentration decreases while those of particles in the moderate $(2.5 \mu \mathrm{m}<r \leq 10.0 \mu \mathrm{m})$ and coarse $(10.0 \mu \mathrm{m}<r \leq 20.0 \mu \mathrm{m})$ modes increase.

Based on Mie theory and the number size distribution of the aerosol, the dust aerosol scattering coefficient and its variation with particle size are calculated and analysed. A fairly close correlation is found with that measured by the nephelometer, for which the correlation coefficients are 0.89 and 0.94 , respectively, at 520 and $700 \mathrm{~nm}$. It shows a Gaussian distribution of dust aerosol scattering coefficient against effective diameter, with a fitting coefficient of 0.96 and centre diameter of $5.5 \mu \mathrm{m}$. The contribution percentages of aerosol within fine, moderate, and coarse modes to dust aerosol scattering coefficient are $20.95 \%, 62.93 \%$, and $16.12 \%$, respectively, meaning that $\mathrm{PM}_{10}$ is a dominant factor in the dust aerosol scattering properties.

\section{Analysis of the vertical structure and size distribution of dust aerosols}

B. Zhou et al.

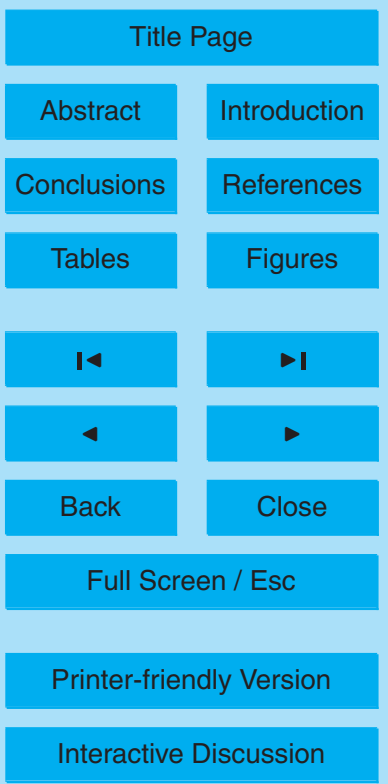




\section{Introduction}

Dust aerosols, which are major aerosols in the lower troposphere (Prospero and Carblson, 1972; Darzi and Winchester, 1982), seriously affect local and global climate change through direct modulation of the surface and atmospheric radiation budgets

5 (Tanré et al., 2003; Li et al., 2004; Woodward et al., 2005; Huang et al., 2010a), modification of cloud properties as cloud condensation nuclei (CCN) (Wurzler et al., 2000; Knopf and Koop, 2006; Koehler et al., 2007), and alteration of the atmospheric temperature by absorption (Ackerman et al., 2000; Huang et al., 2006). Radiative transfer simulations (Ramaswamy et al., 1985; Liao et al., 1998) and satellite remote-sensing 10 studies (Wang et al., 2004; Zhu et al., 2007) have indicated that dust aerosols can modify heating rates, surface longwave and shortwave radiation, and fluxes at the top of the atmosphere (TOA). The vertical structure and size distribution are key parameters affecting the radiative forcing of dust aerosols. On decadal timescales, much research has demonstrated that dust aerosol radiative effects are uncertain, mainly due to a lack of observations of vertical structure and size distribution (Nousiainen, 2009; Koehler et al., 2009; Huang et al., 2010b).

The Loess Plateau is the largest arid/semi-arid area of China, and is also one of the major dust sources (Wang et al., 2001; He et al., 2003; Xia et al., 2005; Kim et al., 2007; Huang et al., 2008b). In recent years, much research on the radiative forcing of dust aerosols over the Loess Plateau has been conducted. In 2005, a China-US joint field experiment was carried out in northern China for the East Asian study of tropospheric aerosols and their impact on regional climate (EAST-AIRC, 2004-) (Li et al., 2007a, b, 2011). Furthermore, the first China-US joint dust field experiment was carried out over north-western China, in which three representative locations (Semi-Arid Climate 25 and Environment Observatory of Lanzhou University [SACOL], Zhangye, and Jingtai) were selected to observe the path of dust storm transportation and to study its radiative properties. In this region, the vertical profile of the dust aerosol extinction coefficient and its optical depth were studied by micropulse lidar (MPL) (Huang et al., 2008a,

\section{Analysis of the vertical structure and size distribution of dust aerosols}

B. Zhou et al.

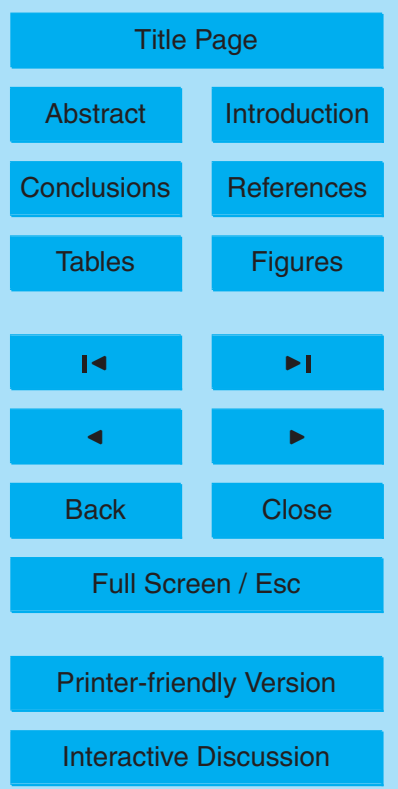


2010; Zhang et al., 2010), Multi-filter Rotation Shadow-band Radiometer (MFRSR) (Ge et al., 2010), and sun photometer (Bi et al., 2011). Dust aerosols were found to exist from the surface to around $9.0 \mathrm{~km}$ near the source region, and their extinction coefficient decreased with height; the dust aerosols from Taklimakan were transported 5 long-range by the upper tropospheric westerly jet (Huang et al., 2008a). The size distribution of aerosols consisted of coarse and fine modes (Bi et al., 2011).

The semi-arid region of the Loess Plateau is a transitional region from arid to semiwet, and its climate is extremely vulnerable. However, only a few observatories are operating in the region (Huang et al., 2008b), resulting in a lack of understanding of 10 the optical properties, size, and concentration distribution of dust aerosols. The lack of data is especially pronounced for the particle shape, which is a key factor in particle polarisation. A lack of information on particle shape will cause significant errors in the retrieval of aerosol optical properties (Sheng et al., 2003). Moreover, less research on the relationship between dust aerosol scattering properties and particle size has been performed. As different size classes of dust aerosol have different effects on the scattering properties, such analysis can facilitate the accurate evaluation of radiative forcing by dust aerosols (Tegen and Lacis, 1996).

SACOL $\left(35^{\circ} 57^{\prime} \mathrm{N}, 104^{\circ} 08^{\prime} \mathrm{E}, 1965.8 \mathrm{~m}\right.$; Fig. 1) was established in 2005 on the Loess Plateau in China. It possesses many advanced instruments, allowing a remarkable understanding of the distribution of dust aerosols and more exact estimation of the dust aerosol effect on local climate (Huang et al., 2008a, b; Zhang et al., 2010; Bi et al., 2011). This paper focuses on the optical properties' vertical structure and size distribution of dust aerosols over SACOL using data from dual-wavelength polarisation lidar, particle sizer, and nephelometer. The variation in dust aerosol optical parameters with altitude, size distribution, concentration variation, and distribution of dust aerosol scattering coefficient against particle diameter are analysed in a case study of a dust storm that lasted from 16 March to 18 March 2010.

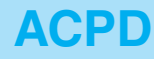

$12,6113-6143,2012$

\section{Analysis of the vertical structure and size distribution of dust aerosols}

B. Zhou et al.

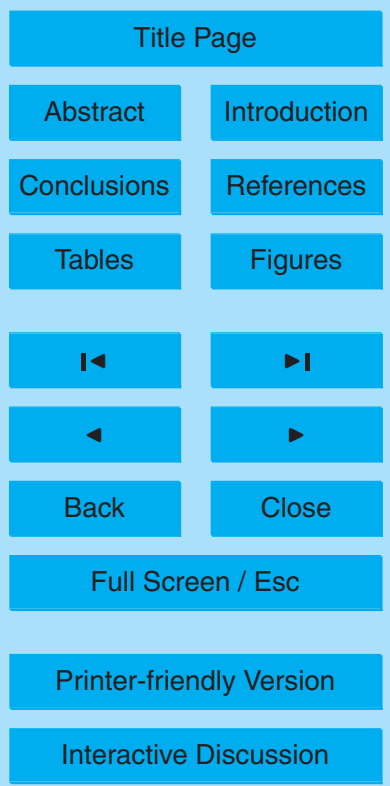




\section{Instruments and methodology}

\subsection{Instruments}

The dual-wavelength polarisation lidar (L2S-SM II) employs an Nd:YAG laser and operates at 532 and $1064 \mathrm{~nm}$, with a polarisation channel at $532 \mathrm{~nm}$. The transmitted laser

5 energy is $20 \mathrm{~mJ}$, with a pulse repetition frequency of $10 \mathrm{~Hz}$. The receiver is a $20-\mathrm{cm}$ Schmidt Cassegrain telescope with a 1-mrad field of view. It can observe aerosol and cloud continuously up to $24 \mathrm{~km}$, with a $6-\mathrm{m}$ range resolution and a $15-\mathrm{min}$ temporal resolution.

The particle sizer (APS-3321) acquires the effective particle diameter using a dual10 parallel laser and low-frequency particle accelerator via observation of the time one particle takes to fly through the laser. It measures the light-scattering intensity by examining each particle's side-scatter signal intensity. It provides an accurate count size distribution for particles with effective diameters of $0.53-20 \mu \mathrm{m}$, and light-scattering intensity for particles ranging from 0.3 to $20 \mu \mathrm{m}$. The nephelometer (M9003) measures 15 the light-scattering coefficient of airborne particles at 450,520 , and $700 \mathrm{~nm}$, with a light-integrating angle of $10-170^{\circ}$ and a temporal resolution of $5 \mathrm{~min}$. All instruments used in this paper are shown in Fig. 1.

\subsection{Methodology}

First, an algorithm to retrieve the aerosol backscattering and extinction coefficients was designed based on the retrieval methods of Collis $(1966,1976)$ and Fernald (1984). The lidar equation can be written as:

$X(z)=E C \beta(z) T^{2}(z)$,

where $z$ is the range from the particle to the lidar, $X(z)$ is the range-corrected backscatter signal at $z, E$ is the transmitted laser pulse energy, $C$ is the calibration constant of

\section{Analysis of the vertical structure and size distribution of dust aerosols}

B. Zhou et al.

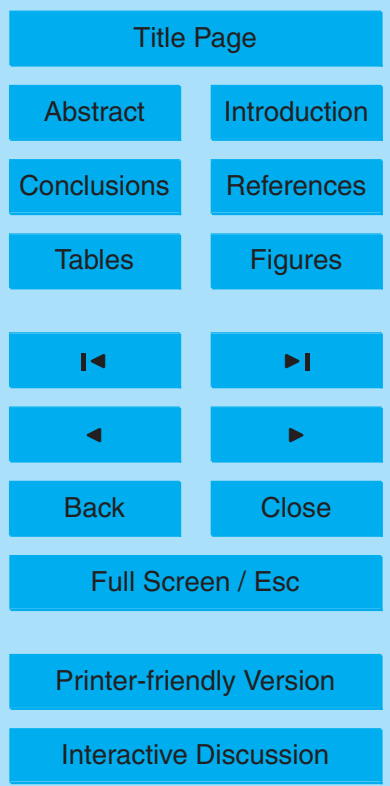


the lidar system, $\beta(z)$ is the backscattering coefficient, $T(z)=\exp \left[-\int_{0}^{z} \sigma\left(z^{\prime}\right) d\left(z^{\prime}\right)\right]$ and is the transmittance, and $\sigma(z)$ is the extinction coefficient.

The measured lidar backscattering signal contains two parts: the atmospheric molecules and the aerosols. Hence, Eq. (1) can be rewritten as:

${ }_{5} X(z)=E C\left[\beta_{1}(z)+\beta_{2}(z)\right] \exp \left\{-2 \int_{0}^{z}\left[\sigma_{1}\left(z^{\prime}\right)+\sigma_{2}\left(z^{\prime}\right)\right] d\left(z^{\prime}\right)\right\}$

where subscripts 1 and 2 stand for aerosol and atmospheric molecules. Then, the lidar ratio $S$ is induced to solve the lidar equation:

$S_{1}=\sigma_{1}(z) / \beta_{1}(z) \quad S_{2}=\sigma_{2}(z) / \beta_{2}(z)$.

In the retrieval, $S_{1}$ and reference height $Z_{C}$ are two key parameters. Inappropriate assumptions will cause retrieval errors in the aerosol extinction coefficient (Xia, 2006; Han, 2007; Tao et al., 2008; Chiang et al., 2008; Wu et al., 2011). Generally, the 'clean' aerosol-free height is set to $Z_{C}$, about $10 \mathrm{~km}$ for a clean atmosphere (Xia, 2006) and below $10 \mathrm{~km}$ in a dust storm (Shimizu et al., 2006; Han, 2007), where the retrieval should be close to the actual atmosphere (Xia, 2006; Tao et al., 2008; Wu et al., 15 2011). Generally, $S_{1}$ is related to the aerosol concentration, size distribution, shape, and composition. For Asian dust aerosols, $S_{1}$ is about $50 \mathrm{sr}$ (Liu et al., 2002; Murayama et al., 2004; Xie et al., 2008). In our study, we set $S_{1}$ to $50 \mathrm{sr}$ in the dust storm and to $20 \mathrm{sr}$ for dust-free conditions (Zhou et al., 2011).

Here the L2S-SM II dual-wavelength lidar can provide a polarisation channel at 532$\mathrm{nm}$. Depolarization ratio is defined as the ratio of the perpendicular to the parallel lidar backscattering return signal and used for distinguishing particle kinds and detecting non-spherical mineral dust particles. In addition, the colour ratio is defined as the ratio of the 1064-nm backscattering intensity to the 532-nm backscattering return signal.

\section{Analysis of the vertical structure and size distribution of dust aerosols}

B. Zhou et al.

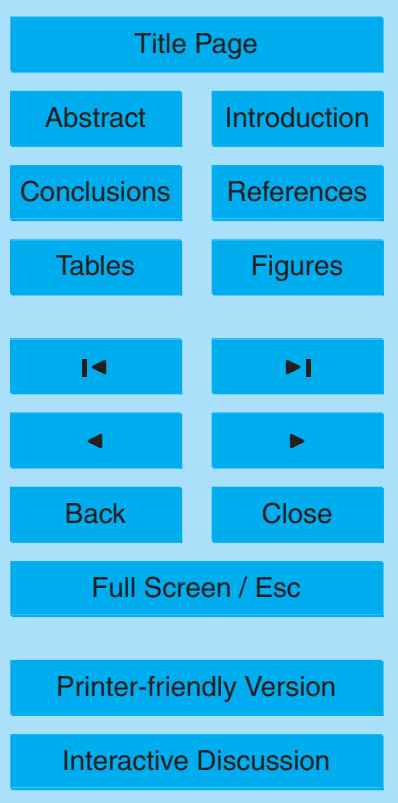


Depolarization ratio and colour ratio are used for depicting aerosol shape and size, respectively.

Second, the size distribution and concentration of dust aerosols were analysed based on the measurements of the particle sizer. Furthermore, the number and mass 5 concentrations of aerosols within fine, moderate, and coarse modes during the dust storm were investigated.

Finally, the dust aerosol scattering coefficient was calculated using Mie theory and measurement of the aerosol number size distribution, and compared with that from the nephelometer. Then, the percentages of aerosols within the fine, moderate, and coarse modes contributing to the dust aerosol scattering coefficient were analysed.

\section{Results}

Statistical analysis of dust events over SACOL in spring 2010 indicated that dust conditions existed on 20 days (11 days in March, 6 in April, and 3 in May). Dust events occurring over SACOL mostly originated from the Taklimakan Desert or Loess Plateau (Huang et al., 2008a). The composition and radiative properties of dust aerosols changed during transportation. Here, the optical properties and size distribution of dust aerosols over SACOL were analysed using depolarisation lidar data and other in-situ measurements during the dust storm on 16-18 March 2010.

This dust event arrived over SACOL at 17:00 (Beijing Time, $1 \mathrm{~h}$ and $3 \mathrm{~min}$ earlier than Lanzhou local time) on 16 March. Figure 2 shows the large-scale weather conditions during this dust storm using National Centers for Environmental Prediction/National Center for Atmospheric Research (NCEP/NCAR) Reanalysis project data $\left(2.5^{\circ} \times 2.5^{\circ}\right)$. Distributions of $700-\mathrm{hPa}$ geopotential height and temperature (a) and $700-\mathrm{hPa}$ wind field (b) at 20:00 on 16 March are shown. A hot high ridge stretched from the Caspian and Aral seas to the northwest of Xinjiang, China, which would have affected the weather conditions over East Asia during its eastward movement. Most of China, except the northwest of Xinjiang, was located in front of the cold low trough; SACOL

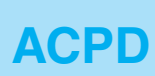

$12,6113-6143,2012$

\section{Analysis of the vertical structure and size distribution of dust aerosols}

B. Zhou et al.

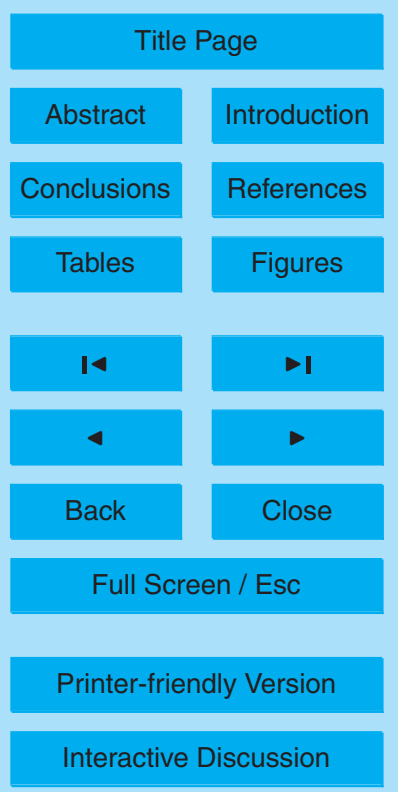


was also in this weather system (Fig. 2a). Northwest wind was dominant over SACOL, and the wind speed ranged from 5.0 to $10.0 \mathrm{~m} \mathrm{~s}^{\circ}$. SACOL was located at the edge of convergence zone (Fig. 2b).

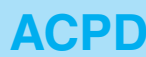

\subsection{Vertical structure of the optical properties of dust aerosols}

5 Figure 3 shows the temporal evolution of the 532-nm backscattering signal (a), 532-nm depolarisation ratio (b), and colour ratio of $1064 / 532 \mathrm{~nm}$ (c) in lidar measurements from 16 March to 18 March 2010. These data show that this dust storm began at 17:00 on 16 March and that dust aerosols were generally distributed in the lower layer (below $3.0 \mathrm{~km}$ ). Before the dust event, the $532-\mathrm{nm}$ depolarisation ratio was $\leq 0.2$; this ratio

10 increased to nearly 0.3 for dust aerosols due to the non-spherical particles in the dust storm. The colour ratio is an index characterising particle size, with higher colour ratios imply that more large particles are present in the atmosphere. The distribution pattern of the colour ratio was similar to that of the depolarisation ratio, and its value ranged from 0.8 to 1.0 (Fig. 3c).

15 Figure 4 shows the temporal evolution of the aerosol extinction coefficient at $532 \mathrm{~nm}$, also retrieved from lidar. A higher dust aerosol extinction coefficient $\left(0.1-1.0 \mathrm{~km}^{-1}\right)$ was distributed in the lower layer (below $3.0 \mathrm{~km}$ ) and was distinct from the non-dust aerosol extinction coefficient $\left(0.001-0.01 \mathrm{~km}^{-1}\right)$.

Figure 5 shows the temporal evolution of the aerosol optical depth (AOD) retrieved 20 from lidar measurements from 08:00 on 16 March to 08:00 on 18 March. Before 17:00 on 16 March, when no dust storm was present, the AOD ranged from 0.005 to 0.12 , showing background aerosol properties over SACOL, which was consistent with the result of Zhou et al. (2011). When the dust storm arrived over SACOL, the AOD increased rapidly to 0.35 , which was evidently induced by dust aerosol loading. In this case, the

25 temporal evolution of the AOD had two peaks: a maximum at 19:00 on 16 March $(A O D=1.35)$ and a sub-maximum at 03:00 on 17 March $(A O D=0.88)$. The average AOD was 0.6 during the dust event, which was obviously different from the background condition. The AOD variation trend was similar to those of the lidar backscattering

\section{Analysis of the vertical structure and size distribution of dust aerosols}

B. Zhou et al.

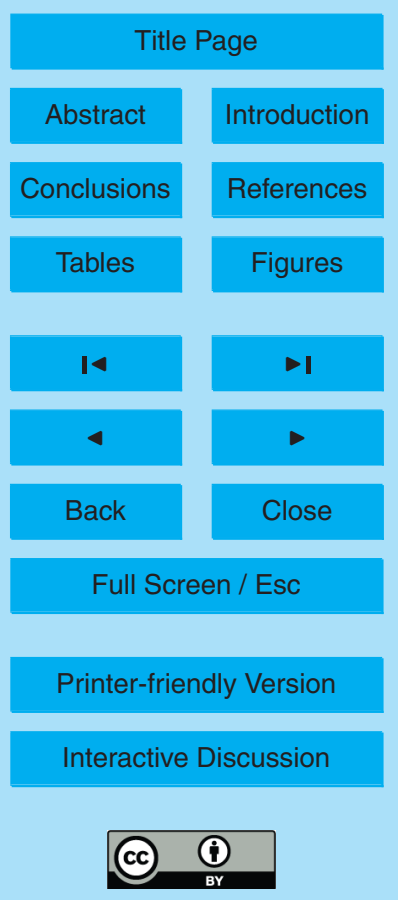


signal, aerosol extinction coefficient, and depolarisation ratio.

To more clearly understand the vertical distribution of aerosol, Fig. 6a shows five vertical profiles of aerosol extinction coefficients. First, dust aerosol mainly existed below $3.0 \mathrm{~km}$, consistent with the results shown in Figs. 3 and 4 . Second, the dust 5 aerosol extinction coefficient increased with height and then decreased rapidly. The heights of the inflections depended on the diffusion conditions and aerosol distribution. Third, the maximum dust aerosol extinction coefficient was $0.91 \mathrm{~km}^{-1}$ at $1.2 \mathrm{~km}$ at $02: 00$ on 17 March. The aerosol extinction coefficient for the dust-free condition was on the order of $10^{-2} \mathrm{~km}^{-1}$, which was much smaller than that of the dust aerosol.

10 The higher depolarisation ratio indicated high deviation from a spherical shape, which has a depolarisation ratio of 0.0. Dual-wavelength polarisation lidar synchronously measures the vertical distributions of the aerosol extinction coefficient and depolarisation ratio. The latter can be used to distinguish spherical from non-spherical particles. In this dust storm, the depolarisation ratio for 532-nm channels of the dust aerosols ranged from 0.2 to 0.4 with mean value of 0.3 and estimation mean relative error of $10 \%$ of the measured value (Sugimoto et al., 2005, 2006) at altitudes ranging from the surface to approximately $3.0 \mathrm{~km}$. In contrast, the depolarisation ratio at $532-$ $\mathrm{nm}$ of the dust-free aerosol ranged from 0.1 to 0.2 (Fig. 6b), showing the large proportion of non-spherical dust aerosols over SACOL. Freudenthalter et al. (2009) noted that the depolarisation ratio and its relative error at 532-nm of Sahara dust aerosols over the Morocco station $\left(30.90^{\circ} \mathrm{N}, 6.90^{\circ} \mathrm{W}\right.$ ) were 0.31 and 0.03 , respectively. In this paper, the mean depolarisation ratio of dust aerosol was very close to this value in despite of the error being in our analysis as well as in Freudenthalter's study. The comparison may imply that both Sahara and Asian dust contain large proportion of non-spherical 25 particles. The difference of depolarisation ratio in vertical distribution may have been caused by different dust sources.

\section{Analysis of the vertical structure and size distribution of dust aerosols}

B. Zhou et al.

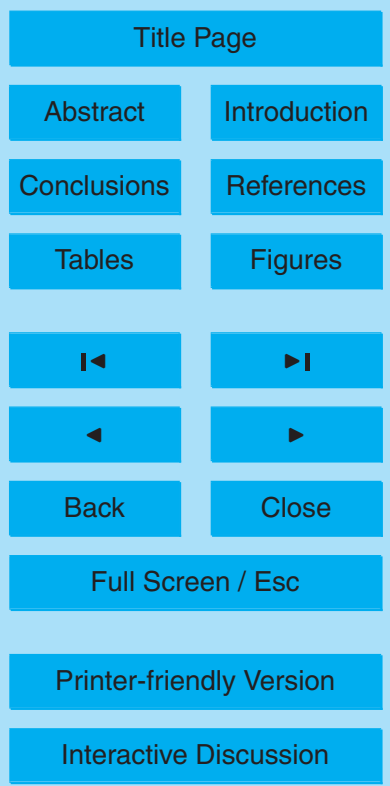




\subsection{Aerosol size distribution}

Based on the measurements of the particle sizer (APS-3321), the mass size distribution during the dust storm had two maximums at 0.7 and $5.0 \mu \mathrm{m}$ (Fig. 7a). The second peak showed a higher concentration under dust conditions than under dust-free con5 ditions. The number size distribution of the dust was log-normal with a maximum near $0.8 \mu \mathrm{m}$, showing that most particles were centralised in the fine mode. In addition, the number of dust particles with diameters ranging from 2.5 to $20.0 \mu \mathrm{m}$ increased (Fig. 7b). Using measurements of number size distribution of Asian dust aerosol in the spring of 1998 in Seoul and on Anmyon Island, Chun et al. (2001) showed that 10 the number of aerosols with diameters of 1.35-10.0 $\mu \mathrm{m}$ increased, while those with diameters $>10.0 \mu \mathrm{m}$ showed no prominent change. Wang et al. (2011) investigated the number size distribution of dust aerosol in spring 2008 at SACOL, and found that the number of aerosols with diameters $>1.0 \mu \mathrm{m}$ increased significantly. The results of our study were similar to those of Chun et al. (2001) and Wang et al. (2011). Some differences are also evident, and may have been caused by the fact that Chun et al. (2001) studied particles downstream of the dust transportation and focused on aerosols with diameters $>10.0 \mu \mathrm{m}$, and that the intensity and source of dust in our study differed from those investigated by Wang et al. (2011).

\subsection{Aerosol concentration distribution}

20 Figure 8 shows the temporal evolution of aerosol mass and number concentration. From 08:00-17:00 on 16 March under dust-free conditions, the aerosol mass concentration was $<0.30 \mathrm{mg} \mathrm{cm}^{-3}$ (mean, $0.11 \mathrm{mg} \mathrm{cm}^{-3}$ ), the mean number concentration was $68 \mathrm{~cm}^{-3}$, and its peak was $1080 \mathrm{~cm}^{-3}$ (appearing at 08:00 on $16 \mathrm{March}$ ). These concentrations may have been caused by the local emission and diffusion conditions.

25 Under dust conditions, the aerosol mass concentration had two peaks appearing at 18:10 on 16 March $\left(1.28 \mathrm{mg} \mathrm{cm}^{-3}\right)$ and $14: 30$ on 17 March $\left(1.15 \mathrm{mg} \mathrm{cm}^{-3}\right)$. The mean aerosol mass concentration was $0.27 \mathrm{mg} \mathrm{cm}^{-3}$ and the mean number concentration

\section{Analysis of the vertical structure and size distribution of dust aerosols}

B. Zhou et al.

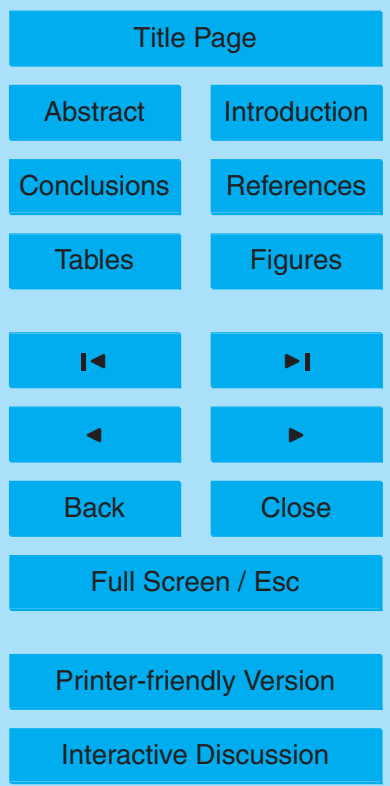


was $62 \mathrm{~cm}^{-3}$. These results show a twofold increase in the mass concentration, while the number concentration shows no obvious change during the dust storm.

Aerosols are classified into fine, moderate, and coarse modes, for which the effective diameters $(r)$ are $<2.5 \mu \mathrm{m}, 2.5-10.0 \mu \mathrm{m}$, and 10.0-20.0 $\mu \mathrm{m}$, respectively. During 5 dust storms, the percentages of fine, moderate, and coarse modes contributing to aerosol number concentration were $88.83 \%, 11.02 \%$, and $0.14 \%$, respectively; under dust-free conditions, these percentages were $98.49 \%, 1.5 \%$, and $0.01 \%$, respectively. Analysis showed that the percentage of fine-mode aerosols decreased while those of moderate- and coarse-mode aerosols increased during the dust storm in comparison with dust-free conditions. The increase was particularly large for the moderate-mode aerosols (Fig. 9), which indicated that numerous coarse particles were loaded into the atmosphere under dust conditions. Figure 10 shows the percentages of aerosol mass concentration in total mass concentration within the (a) fine, (b) moderate, and (c) coarse modes. During dust storms, the percentage of fine, moderate and coarse modes were $11.15 \%, 73.32 \%$, and $15.53 \%$, respectively; under dust-free conditions, these percentages were $28.05 \%, 66.92 \%$, and $5.03 \%$, respectively. For dust aerosols, the moderate mode was the main contributor to mass concentration, followed by the coarse mode; under dust-free conditions, the moderate mode was the main contributor to mass concentration, followed by the fine mode.

\subsection{Scattering properties of the dust aerosols}

Mie theory is developed based on perfect spherical particle. As dust aerosols diverge from spherical shape away, so using this theory to calculate on the scattering of dust aerosol will cause error (Müller et al., 2009; Wiegner et al., 2009; Gasteiger et al., 2011), Assuming that non-spherical particles are homogeneous spheres, the relative errors of both the extinction efficiency and the single scattering albedo are less than $1 \%$ (Fu et al., 2009).

ACPD

12, 6113-6143, 2012

\section{Analysis of the vertical structure and size distribution of dust aerosols}

B. Zhou et al.

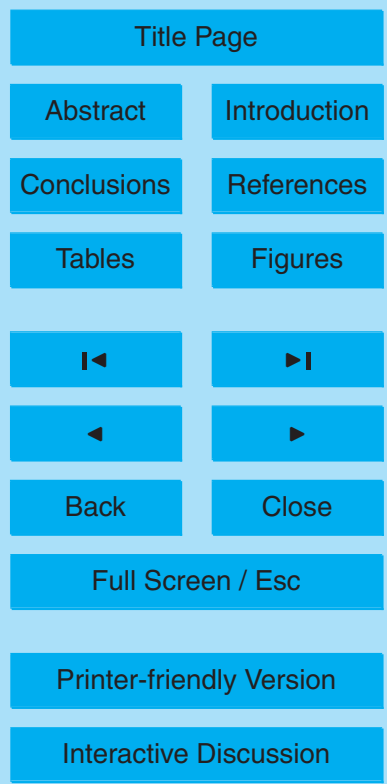


Based on Mie theory and measurement of the size distribution of aerosol number concentration, the scattering coefficient of dust aerosol was calculated and its correlation with effective diameter was analysed.

Figure 11 shows a comparison of dust aerosol scattering coefficients obtained by

5 Mie theory calculations and nephelometer (M9300) observations at $520 \mathrm{~nm}$ (a) and $700 \mathrm{~nm}$ (b). The calculated dust aerosol scattering coefficients at 520 and $700 \mathrm{~nm}$ showed a rather close linear correlation with the observed coefficients (correlation coefficients of 0.89 and 0.94 , respectively), showing that the calculated surface dust aerosol scattering coefficients were credible. Figure 12 shows the distribution of dust 10 aerosol scattering coefficients plotted against effective diameter. The distribution was Gaussian, with a fitting coefficient of 0.96 and a centre diameter of $5.5 \mu \mathrm{m}$.

To understand the scattering properties of $\mathrm{PM}_{2.5}, \mathrm{PM}_{10}$, and $\mathrm{PM}_{20}$, Fig. 13 shows the contribution percentage of aerosols within the fine, moderate, and coarse modes to the dust aerosol scattering coefficient. The values were $20.95 \%, 62.93 \%$, and tions of $\mathrm{PM}_{2.5}$ and $\mathrm{PM}_{10}$ to the scattering coefficient were $20.95 \%$ and $83.88 \%$ during the dust storm. These results show that $\mathrm{PM}_{10}$ was the dominant factor in the dust scattering properties. The analysis based on nephelometer (M9300) and particulate monitor (TEOM 1400a) measurements showed a close linear correlation between the dust aerosol scattering coefficient and $\mathrm{PM}_{10}$ concentration (Zhang et al., 2010). Our result was similar to that of Zhang et al. (2010), with the difference that we studied the quantitative effect of $\mathrm{PM}_{2.5}$ and $\mathrm{PM}_{10}$ on dust scattering properties.

\section{Conclusion and discussion}

The vertical structure and size distribution of dust aerosols over the semi-arid region of 25 the Loess Plateau are analysed through the case study of a dust storm occurring on 16-18 March 2010, using data from a dual-wavelength polarisation lidar, nephelometer, and particle sizer from SACOL.
$12,6113-6143,2012$

\section{Analysis of the vertical structure and size distribution of dust aerosols}

B. Zhou et al.

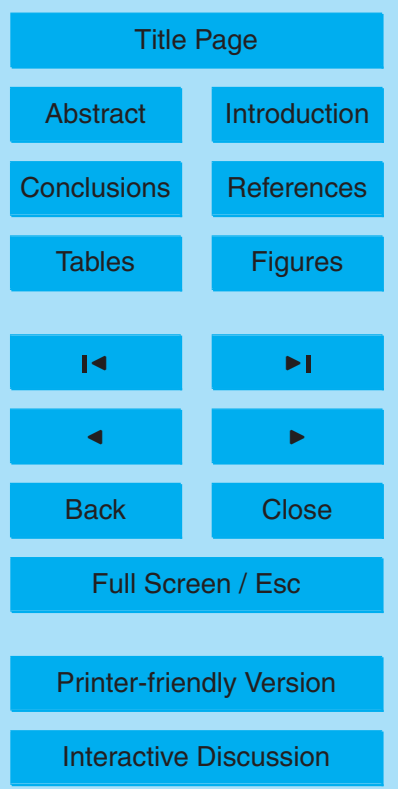


The dust aerosols are distributed mostly within the lowermost $3.0 \mathrm{~km}$ of the atmospheric column, where many large asymmetrical particles are present. During the dust storm, the mass size distribution of dust aerosols has two peaks at $0.7 \mu \mathrm{m}$ and $5.0 \mu \mathrm{m}$, respectively; the number size distribution of dust aerosols shows a log-normal distribu5 tion with a maximum near $0.8 \mu \mathrm{m}$. Particles in the fine mode dominate, but the number concentration of aerosols in the fine mode decreases while those in the moderate and coarse modes increase.

The dust aerosol scattering coefficients of 520 and $700 \mathrm{~nm}$ are correlated quite closely with those measured by the nephelometer, with correlation coefficients of 0.89 10 and 0.94 , respectively. The distribution of dust aerosol scattering coefficients with respect to the effective diameter is Gaussian, with a fitting coefficient of 0.96 and a centre diameter of $5.5 \mu \mathrm{m}$. The contribution percentages of fine-, moderate-, and coarsemode aerosols to the scattering coefficient of dust aerosols are $20.95 \%, 62.93 \%$, and $16.12 \%$, respectively, showing that $\mathrm{PM}_{10}$ is the dominant factor in the dust aerosol 15 scattering properties.

It makes sense to assess the radiative characteristics of dust aerosols over the semiarid region of the Loess Plateau in China based on multi-instrument observations at SACOL. However, the particle diameter limitation of the particle sizer, with the effective diameter of observed particles ranging from 0.53 to $20.0 \mu \mathrm{m}$, may have introduced errors into the comparison. Further and more comprehensive observations are needed in the application of lidar and other instruments to study other properties of dust aerosols, especially their absorbing properties.

Acknowledgements. The research is supported by the National Natural Science Foundation of China (41075104), the National Important Science Research Program of China (2012CB955302), and the Fundamental Research Funds for the Central Universities of Lanzhou University (Izujbky-2011-5). We gratefully thank the stuff of SACOL providing the used data, also we would like to thank Warren J. Wiscombe for the great help in our using of Mie Code.

\section{ACPD}

$12,6113-6143,2012$

\section{Analysis of the vertical structure and size distribution of dust aerosols}

B. Zhou et al.

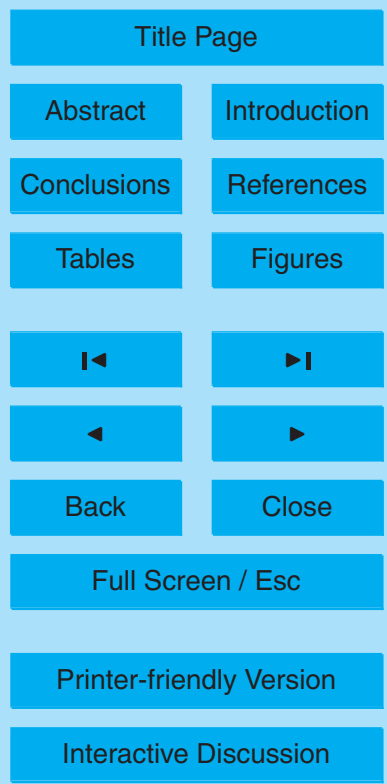




\section{References}

Ackerman, A. S., Toon, O. B., Stevens, D. E., Heymsfield, A. J., Ramanathan, V., and Welton, E. J.: Reduction of tropical cloudiness by soot, Science, 288, 1042-1047, doi:10.1126/science.288.5468.1042, 2000.

5 Bi, J. R., Huang, J. P., Fu, Q., Wang, X., Shi, J. S., Zhang, W., Huang, Z. W., and Zhang, B. T.: Toward characterization of the aerosol optical properties over Loess Plateau of Northwestern China, J. Quant. Spectrosc. Ra., 112, 346-360, 2011.

Chiang, C. W., Das, S. K., and Nee, J. B.: An iterative calculation to derive extinction-tobackscatter ratio based on lidar measurements, J. Quant. Spectrosc. Ra., 109, 1187-1195, 102008.

Chun, Y. S., Kim, J. R., Choi, J. C., Boo, K. N., Oh, S. N., and Lee, M. Y.: Characteristic number size distribution of aerosol during Asian dust period in Korea, Atmos. Environ., 35, 2715-2721, 2001.

Collis, R. T. H.: Lidar: a new atmosphere probe, Q. J. Roy. Meteor. Soc., 92, 220-230, 1966.

15 Collis, R. T. H. and Russell, P. B.: Lidar measurements of particles and gases by elastic backscattering and differential absorption, in: Laser Monitoring of the Atmosphere, SpringerVerlag, Hinkley, E. D., Germany, 14, 71-151, 1976.

Darzi, M. and Winchester, J. W.: Resolution of basaltic and continental aerosol components during spring and summer within the boundary layer of Hawaii, J. Geophys. Res., 87, 72627272, 1982.

Fernald, F. G.: Analysis of atmospheric lidar observations: some comments, Appl. Optics, 23, 652-653, 1984.

Freudenthalter, V., Esselborn, M., Wiegner, M., Heese, B., Tesche, M., Ansmann, A., Müller, D., Althausen, D., Wirth, M., Fix, A., Ehret, G., Knippertz, P., Toledano, C., Gasteiger, J., Gerhammer, M., and Seefeldner, C.: Depolarization ratio profiling at several wavelengths in pure Saharan dust during SAMUM 2006, Tellus B, 61, 165-179, 2009.

Fu, Q., Thorsen, T. J., Su, J., Ge, J., and Huang, J. P.: Test of Mie based single-scattering properties of non-spherical dust aerosols in radiative flux calculations, J. Quant. Spectrosc. Ra., 110, 1640-1653, doi:10.1016/j.jqsrt.2009.03.010, 2009.

Gasteiger, J., Gro, S., Freudenthaler, V., and Wiegner, M.: Volcanic ash from Iceland over Munich: mass concentration retrieved from ground-based remote sensing measurements, Atmos. Chem. Phys., 11, 2209-2223, doi:10.5194/acp-11-2209-2011, 2011.

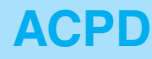

$12,6113-6143,2012$

\section{Analysis of the vertical structure and size distribution of dust aerosols}

B. Zhou et al.

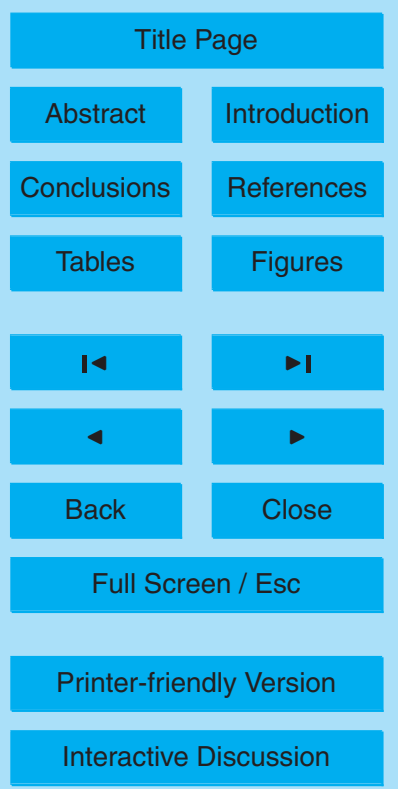


Ge, J. M., Su, J., Ackerman, T. P., Fu, Q., Huang, J. P., and Shi, J. S.: Dust aerosol optical properties retrieval and radiative forcing over northwestern China during the 2008 ChinaU.S. joint field experiment, J. Geophys. Res., 115, D00K12, doi:10.1029/2009JD013263, 2010.

5 Han, X.: Retrieval of Lanzhou urban and suburban aerosol radiative properties using lidar measurement, M. S. thesis, Lanzhou University, China, 51 pp., 2007 (in Chinese).

He, L. S., Ma, B. X., Du, W. K., and Ren, H. Y.: Characteristics of urban pollution under arid and semi-arid condition on the Loess Plateau in north western China: examples of form a city in the northwestern China, Geology in China, 30, 442-448, 2003 (in Chinese).

10 Huang, J. P., Lin, B., Minnis, P., Wang, T. H., Wang, X., Hu, Y. X., Yi, Y. H., and Ayers, J. K.: Satellite-based assessment of possible dust aerosols semi-direct effect on cloud water path over East Asia, J. Geophys. Res., 33, L19802, doi:10.1029/2006GL026561, 2006.

Huang, J. P., Minnis, P., Chen, B., Huang, Z. W., Liu, Z. Y., Zhao, Q. Y., Yi, Y. H., and Ayer, J. K.: Long-range transport and vertical structure of Asian dust from CALIPSO and surface measurements during PACDEX, J. Geophys. Res., 113, D23212, doi:10.1029/2008JD010620, 2008a.

Huang, J. P., Zhang, W., Zuo, J. Q., Bi, J. R., Shi, J. S., Wang, X., Chang, Z. L., Huang, Z. W., Yang, S., Zhang, B. D., Wang, G. Y., Feng, G. H., Yuan, J. Y., Zhang, L., Zuo, H. C., Wang, S. G., Fu, C. B., and Chou, J. F.: An overview of the semi-arid climate and environment research observatory over the Loess Plateau, Adv. Atmos. Sci., 25, 906-921, 2008b.

Huang, J., Minnis, P., Yan, H., Yi, Y., Chen, B., Zhang, L., and Ayers, J. K.: Dust aerosol effect on semi-arid climate over Northwest China detected from A-Train satellite measurements, Atmos. Chem. Phys., 10, 6863-6872, doi:10.5194/acp-10-6863-2010, 2010a.

Huang, Z. W., Huang, J. P., Bi, J. R., Wang, G. Y., Wang, W. C., Fu, Q., Li, Z. Q., Tsay, S. C., and Shi, J. S.: Dust aerosol vertical structure measurements using three MPL lidars during 2008 China-U.S. joint dust field experiment, J. Geophys. Res., 115, D00K15, doi:10.1029/2009JD013273, 2010b.

Kim, S. W., Yoon, S. C., Kim, J., and Kim, S. Y.: Seasonal and monthly variations of columnar aerosol optical properties over East Asia determined from multi-year MODIS, LIDAR, and

30 AERONET Sun/sky radiometer measurements, Atmos. Environ., 41, 1634-1651, 2007.

Knopf, D. A. and Koop, T.: Heterogeneous nucleation of ice on surrogates of mineral dust, J. Geophys. Res., 111, D12201, doi:10.1029/2005JD006894, 2006.

Koehler, K. A., Kreidenweis, S. M., Demott, P. J., and Petters, M. D.: Potential impact of

\section{Analysis of the vertical structure and size distribution of dust aerosols}

B. Zhou et al.

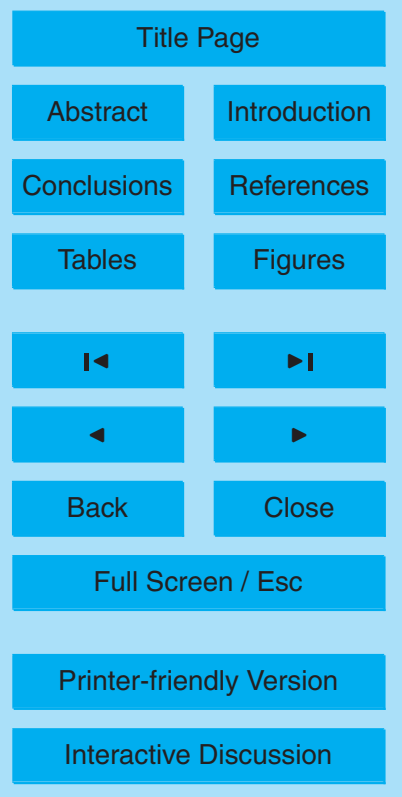


Owens (dry) Lake dust on warm and cold cloud formation, J. Geophys. Res., 112, D12210, doi:10.1029/2007JD008413, 2007.

Koehler, K. A., Kreidenweis, S. M., Demott, P. J., Petters, M. D., Prenni, A. J., and Carrico, C. M.: Hygroscopicity and cloud droplet activation of mineral dust aerosol, Geophys. Res. Lett., $5 \quad$ 36, L08805, doi:10.1029/2009GL037348, 2009.

$\mathrm{Li}, \mathrm{F}$., Vogelmann, A. M., and Ramanathan, V.: Saharan dust aerosol radiative forcing measured from space, J. Climate, 17, 2558-25571, 2004.

Li, Z. Q., Chen, H., Cribb, M., Dickerson, R., Holben, B., Li, C., Lu, D., Luo, Y., Maring, H., Shi, G., Tsay, S. C., Wang, P., Wang, Y., Xia, X., Zheng, Y., Yuan, T., and Zhao, F.: Preface to special section on East Asian Studies of Tropospheric Aerosols: An International Regional Experiment (EAST-AIRE), J. Geophys. Res., 112, D22S00, doi:10.1029/2007JD008853, 2007a.

Li, Z. Q., Xia, X. A., Cribb, M., Mi, W., Holben, B., Wang, P. C., Chen, H. B., Tsay, S. C., Eck, T. F., Zhao, F. S., Dutton, E. G., and Dickerson, R. E.: Aerosol optical properties and their radiative effects in northern China, J. Geophys. Res., 112, D22S01, doi:10.1029/2006JD007382, 2007b.

Li, Z. Q., Li, C., Chen, H., Tsay, S. C., Holben, B., Huang, J. P., Li, B., Maring, H., Qian, Y., Shi, G., Xia, X., Yin, Y., Zheng, Y., and Zhuang, G.: East Asian Studies of Tropospheric Aerosols and their Impact on Regional Climate (EAST-AIRC): An overview, J. Geophys. Res., 116, D00K34, doi:10.1029/2010JD015257, 2011.

Liao, H. and Seinfeld, J. H.: Radiative forcing by mineral dust aerosols: sensitivity to key variables, J. Geophys. Res, 103, 637-645, 1998.

Liu, Z. Y., Sugimoto, N., and Murayama, T.: Extinction-to-backscatter ratio of Asian dust observed with high-spectral-resolution lidar and Raman Lidar, Appl. Optics, 41, 2760-2767, 252002.

Müller, T., Schladitz, A., Massling, A., Kaaden, N., Kandler, K., and Wiedensohler, A.: Spectral absorption coefficients and imaginary parts of refractive indices of Saharan dust during SAMUM-1, Tellus B, 61, 79-95, doi:10.1111/j.1600-0889.2008.00399.x, 2009.

Murayama, T., Müller, D., Wada, K., Shimizu, A., Sekiguchi, M., and Tsukamoto T.: Characterization of Asian dust and Siberian smoke with multi-wavelength Raman lidar over Tokyo Japan in spring 2003, Geophys. Res. Lett., 31, L23103, doi:10.1029/2004GL021105, 2004.

Nousiainen, T.: Optical modeling of mineral dust particles: A review, J. Quant. Spectrosc. Ra., 110, 1261-1279, 2009.

\section{Analysis of the vertical structure and size distribution of dust aerosols}

B. Zhou et al.

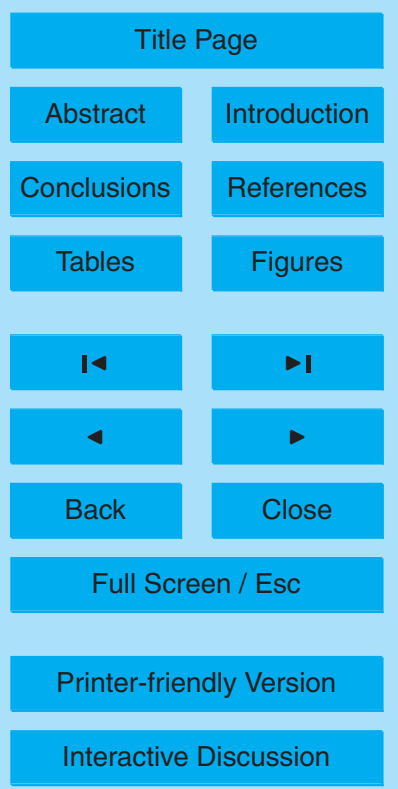


Prospero, J. M. and Carblson, T. N.: Vertical and areal distribution dust over the western equatorial North Atlantic Ocean, J. Geophys. Res., 77, 5255-5265, 1972.

Ramaswamy, V. and Kiehl, J. T.: Sensitivities of the radiative forcing due to large loadings of smoke and dust aerosols, J. Geophys. Res., 90, 5597-5613, 1985.

5 Sheng, P. X., Mao, J. T., Li, J. G., Zhang, A. S., Sang, J. G., and Pan, N. X.: Atmospheric physics, Peking University Press, Wang Yan, China, 416-433, 2003 (in Chinese).

Shimizu, A., Sugimoto, N., Matsui, I., Arao, K., Uno, I., Murayama, T., Kazuma, N., Kazuma, A., Uchiyama, A., and Yamazaki, A.: Continuous observations of Asian dust and other aerosols by polarization lidars in China and Japan during ACE-Asia, J. Geophys. Res., 109, D19S17, doi:10.1029/2002JD003253, 2004.

Sugimoto, N. and Lee, C. H.: Characteristics of dust aerosols inferred from lidar depolarization measurements at two wavelengths, Appl. Optics, 45, 7468-7474, 2006.

Sugimoto, N., Shimizu, A., Matsui, I., Uno, I., Arao, K., Dong, X., Zhao, S., Zhou, J., and Lee, C. $\mathrm{H}$.: Study of Asian dust phenomena in 2001-2003 using a net work of continuously operated,

15 Water, Air, Soil Pollut.: Focus, 5, 145-157, 2005.

Tanré, D., Haywood, J., Pelon, J., Léon, J. F., Chatenet, B., Formenti, P., Francis, P., Goloub, P., Highwood, E. J., and Myhre, G.: Measurement and modeling of the Saharan dust radiative impact: Overview of the Saharan Dust Experiment (SHADE), J. Geophys. Res., 108, D18, doi:10.1029/2002JD003273, 2003.

20 Tao, Z., Mccormick, M. P., and Wu, D.: A comparison method for space-borne and groundbased lidar and its application to the CALIPSO lidar, Appl. Phys. B, 91, 639-644, 2008.

Tegen, I. and Lacis, A. A.: Modeling of particle size distribution and its influence on the radiative properties of mineral dust aerosol, J. Geophys. Res., 101, 19237-19244, 1996.

Wang, J., Fu, B. J., Qu, Y., and Chen, L. D.: Soil nutrients in relation to land use and landscape position in the semi-arid small catchment on the loess plateau in China, J. Arid Environ., 48, 537-550, 2001.

Wang, H., Shi, G. Y., Teruo, A., Wang, B., and Zhao, T. L.: Radiative forcing due to dust aerosol over east Asia-north Pacific region during spring, 2001, Chinese Sci. Bull., 49, 2212-2219, 2004.

so Wang, Z. H., Zhang, W., Shi, J. S., Huang, J. P., Chen, Y., Bi, J. R., and Zhang, B. T.: Concentration and size distribution of atmospheric particles over semi-arid area, J. Desert Res., 30, 1186-1193, 2011 (in Chinese).

Wiegner, M., Gasteiger, J., Kandler, K., Weinzierl, B., Rasp, K., Esselborn, M., Freudenthaler,

\section{Analysis of the vertical structure and size distribution of dust aerosols}

B. Zhou et al.

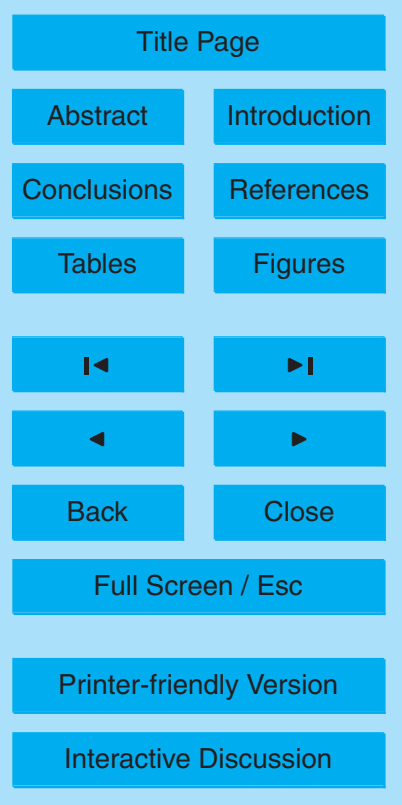


V., Heese, B., Toledano, C., Tesche, M., and Althausen, D.: Numerical simulations of optical properties of Saharan dust aerosols with emphasis on lidar applications, Tellus B, 61, 180194, doi:10.1111/j.1600-0889.2008.00381.x, 2009.

Woodward, S., Roberts, D. L., and Betts, R. A.: A simulation of the effect of climate 5 change-induced desertification on mineral dust aerosol, Geophys. Res. Lett., 232, L18810, doi:10.1029/2005GL023482, 2005.

Wu, D., Wang, Z., Wang, B., Zhou, J., and Wang, Y.: CALIPSO validation using ground-based lidar in Hefei (31.9 N, 117.2 E), China, Appl. Phys. B, 102, 185-195, 2011.

Wurzler, S., Reisin, T. G., and Levin, Z.: Modification of mineral dust particles by cloud processing and subsequent effects on drop size distributions, J. Geophys. Res., 105, 4501-4512, 2000.

Xia, J. R.: Lidar measurement of atmospheric aerosol radiative properties over Lanzhou, M.S. thesis, Lanzhou University, China, 19-28 pp., 2007 (in Chinese).

Xia, X. A., Chen, H. B., Wang, P. C., Zong, X. M., Qiu, J. H., and Philippe, G.: Aerosol properties 15 and their spatial and temporal variations over north China in spring 2001, Tellus B, 57, 28-39, 2005.

Xie, C. B., Nishizama, T., Sugimoto, N., Matsui, I., and Wang, Z. F.: Characteristics of aerosol optical properties in pollution and Asian dust episodes over Beijing, China, Appl. Optics, 47, 4845-4851, 2008.

20 Zhang, L., Cao, X., Bao, J., Zhou, B., Huang, J., Shi, J., and Bi, J.: A case study of dust aerosol radiative properties over Lanzhou, China, Atmos. Chem. Phys., 10, 4283-4293, doi:10.5194/acp-10-4283-2010, 2010.

Zhou, B., Zhang, L., Cao, X. J., Han, X., Zhang, W., and Feng, G. H.: Analysis of atmospheric aerosol optical properties with lidar data in Lanzhou suburb, Plateau Meteorology, 30, 10111017, 2011 (in Chinese).

Zhu, A. H., Ramanathan, V., Li, F., and Kim, D.: Dust plumes over the Pacific, Indian, and Atlantic oceans: Climatology and radiative impact, J. Geophys. Res., 112, D16208, doi:10.1029/2007JD008427, 2007.

\section{ACPD}

12, 6113-6143, 2012

\section{Analysis of the vertical structure and size distribution of dust aerosols}

B. Zhou et al.

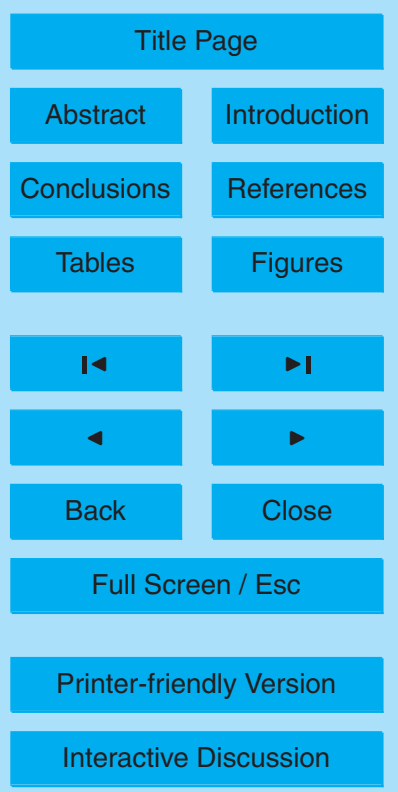



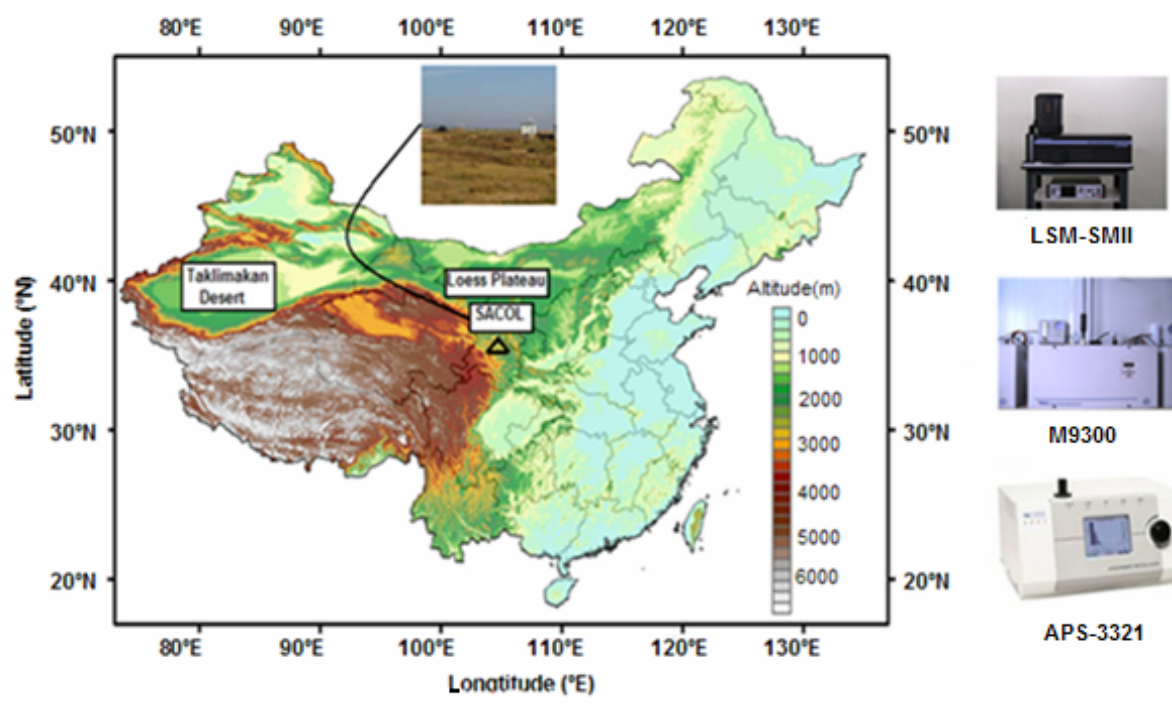

LSM-SMII

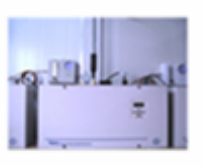

M9300

1

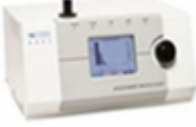

APS-3321

Fig. 1. Location of SACOL and relevant instruments.

\section{ACPD}

12, 6113-6143, 2012

\section{Analysis of the vertical structure and size distribution of dust aerosols}
B. Zhou et al.

Title Page

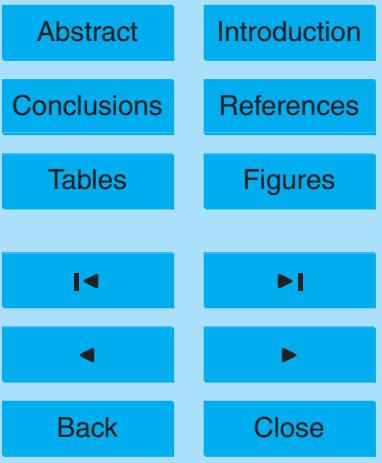

Full Screen / Esc

Printer-friendly Version

Interactive Discussion 


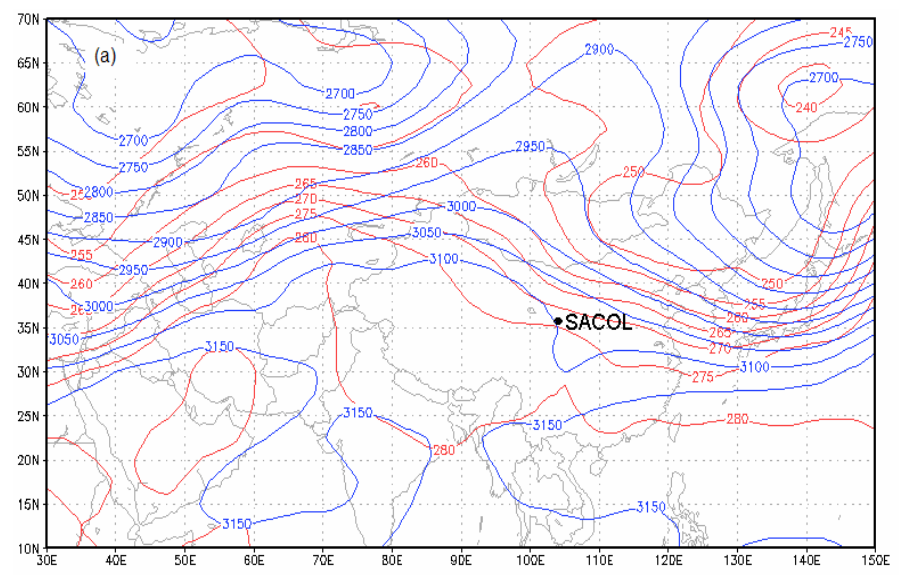

\section{ACPD}

12, 6113-6143, 2012

\section{Analysis of the vertical structure and size distribution of dust aerosols}

B. Zhou et al.

Title Page

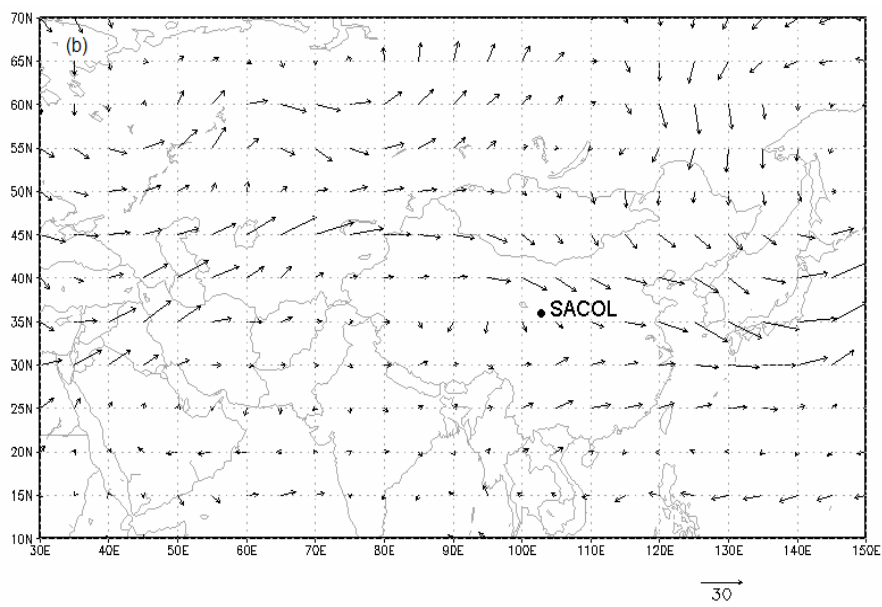

Abstract

Introduction

Conclusions

References

Tables

Figures

14

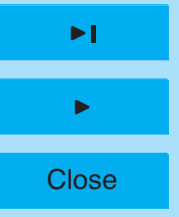

Back

Close

Full Screen / Esc

Printer-friendly Version

Fig. 2. Distributions of (a) 700-hPa geopotential height and temperature, and (b) 700-hPa wind field at 20:00 on 16 March 2010. 


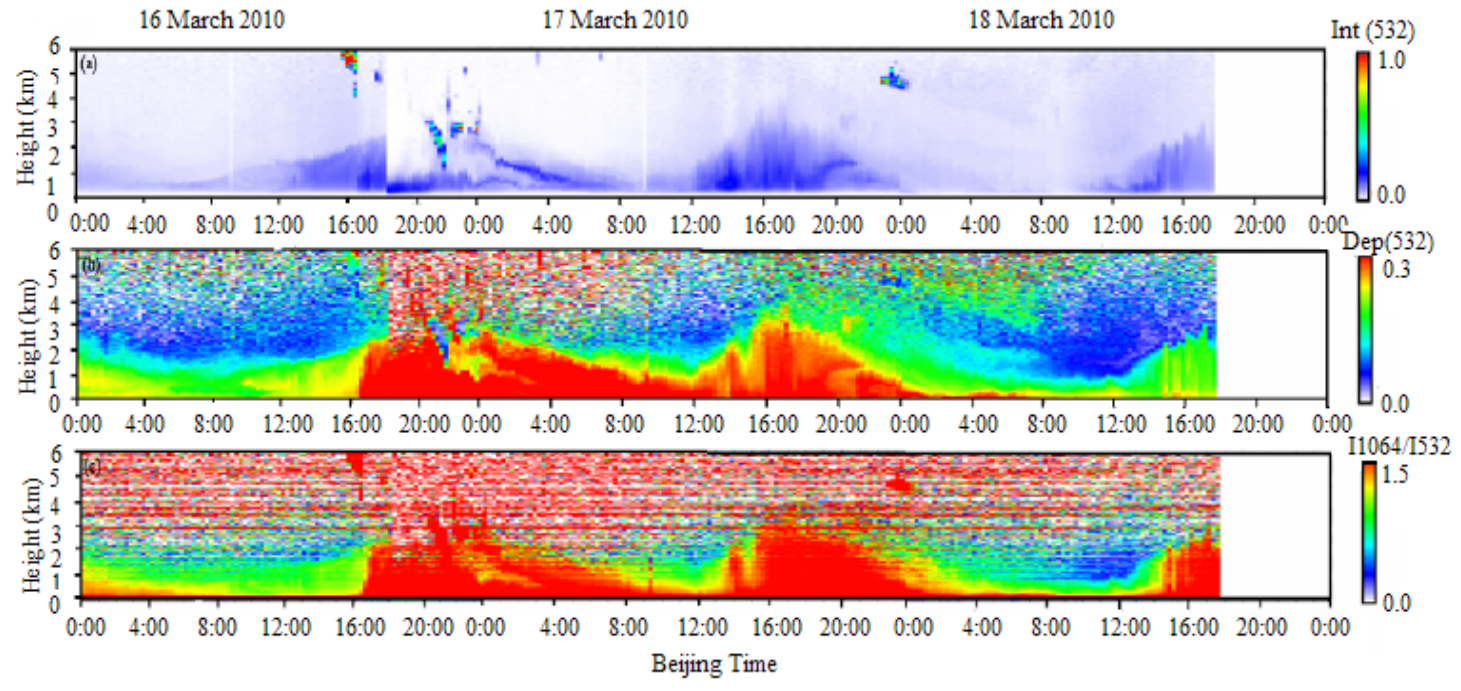

Fig. 3. Temporal evolution of (a) 532-nm backscattering signal, (b) 532-nm depolarisation ratio, and (c) colour ratio of 1064/532 $\mathrm{nm}$ from lidar.

\section{ACPD}

$12,6113-6143,2012$

\section{Analysis of the vertical structure and size distribution of dust aerosols}
B. Zhou et al.

Title Page

Abstract

Introduction

Conclusions

References

Tables

Figures

14

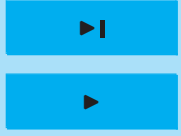

Back

Close

Full Screen / Esc

Printer-friendly Version

Interactive Discussion 


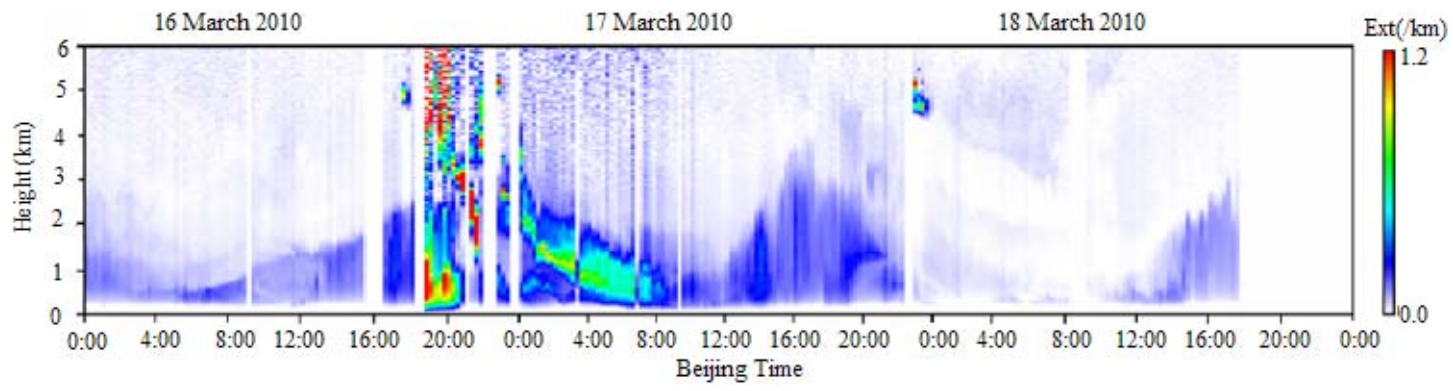

Fig. 4. Temporal evolution of 532-nm aerosol extinction coefficient in a vertical section from lidar.

$12,6113-6143,2012$

\section{Analysis of the vertical structure and size distribution of dust aerosols}

B. Zhou et al.

Title Page

\section{Abstract}

Conclusions

Tables

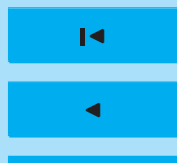

Back

Full Screen / Esc

Printer-friendly Version

Interactive Discussion

Figures

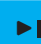

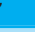

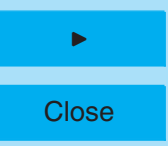




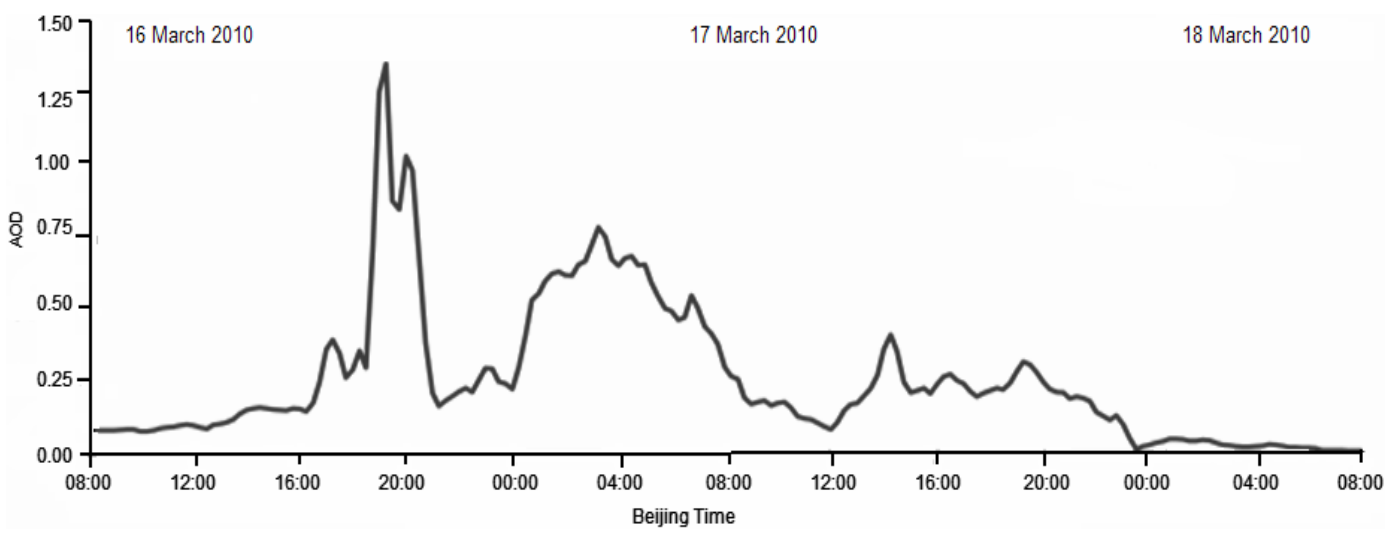

Fig. 5. Temporal evolution of the AOD from 08:00 on 16 March to 08:00 on 18 March.

\section{ACPD}

12, 6113-6143, 2012

\section{Analysis of the vertical structure and size distribution of dust aerosols}
B. Zhou et al.

\section{Title Page}

\section{Abstract}

Introduction

Conclusions

References

Tables

Figures

14

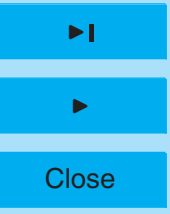

Back

Full Screen / Esc

Printer-friendly Version

Interactive Discussion 

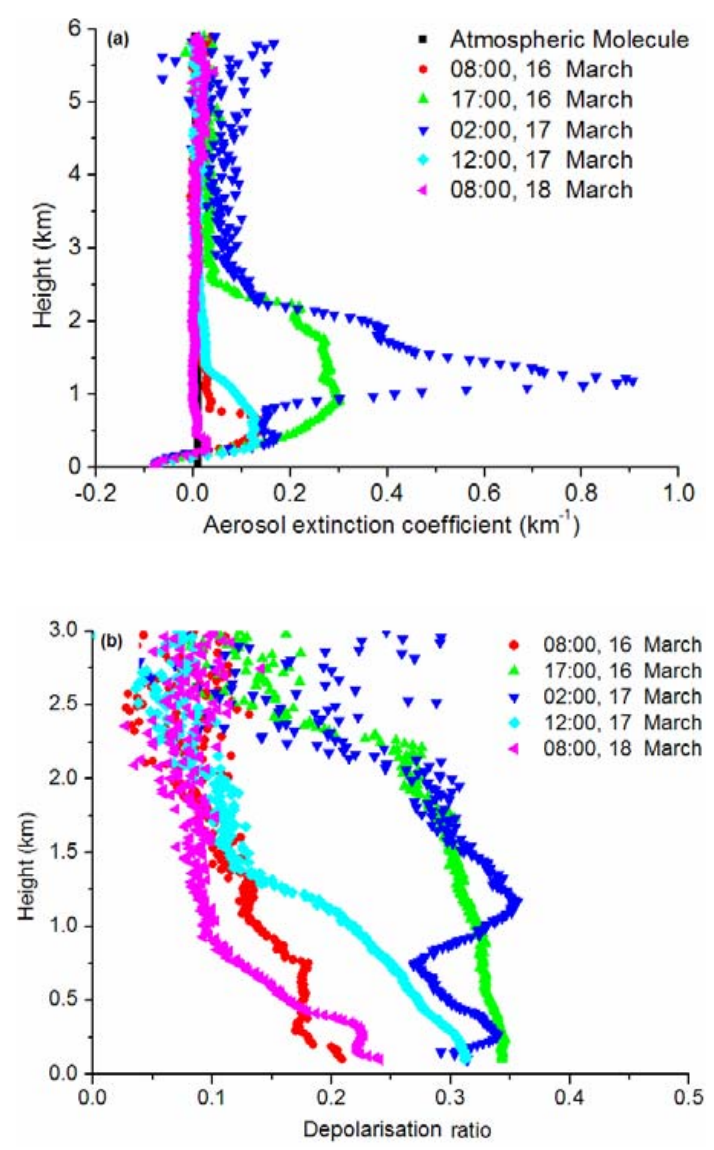

Fig. 6. Vertical profiles of (a) aerosol extinction coefficient and (b) depolarisation ratio from lidar. Three profiles were obtained under dust-storm conditions and the other two were obtained under dust-free conditions. The dust storm arrived over SACOL at 17:00 (Beijing Time) on 16 March and ended at 00:00 on 18 March 2010.

\section{ACPD}

12, 6113-6143, 2012

\section{Analysis of the vertical structure and size distribution of dust aerosols}

B. Zhou et al.

Title Page

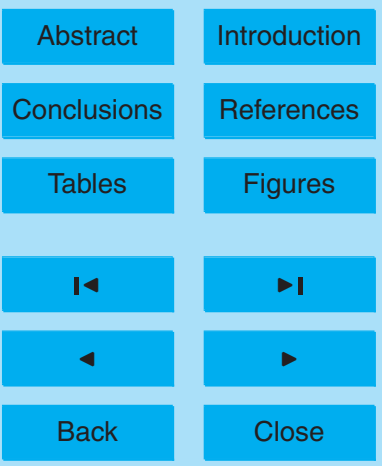

Full Screen / Esc

Printer-friendly Version

Interactive Discussion 


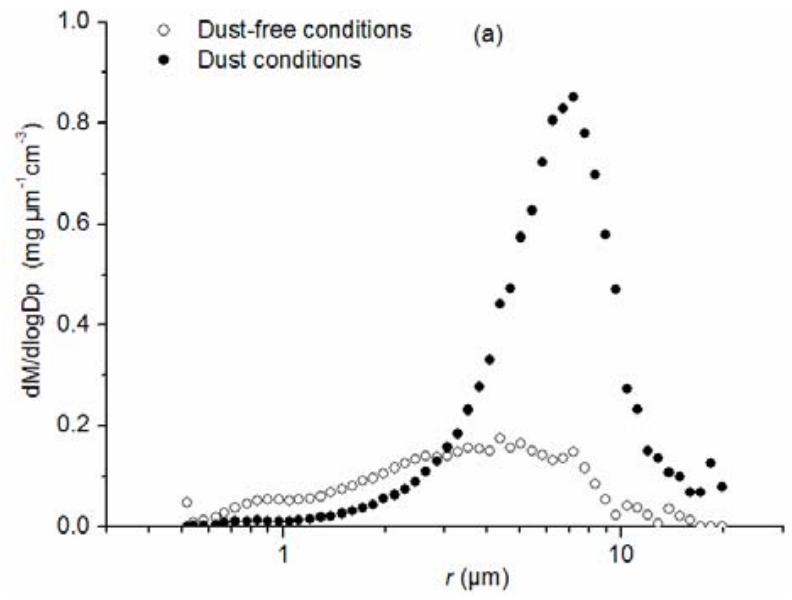

\section{ACPD}

$12,6113-6143,2012$

\section{Analysis of the vertical structure and size distribution of dust aerosols}
B. Zhou et al.

Title Page
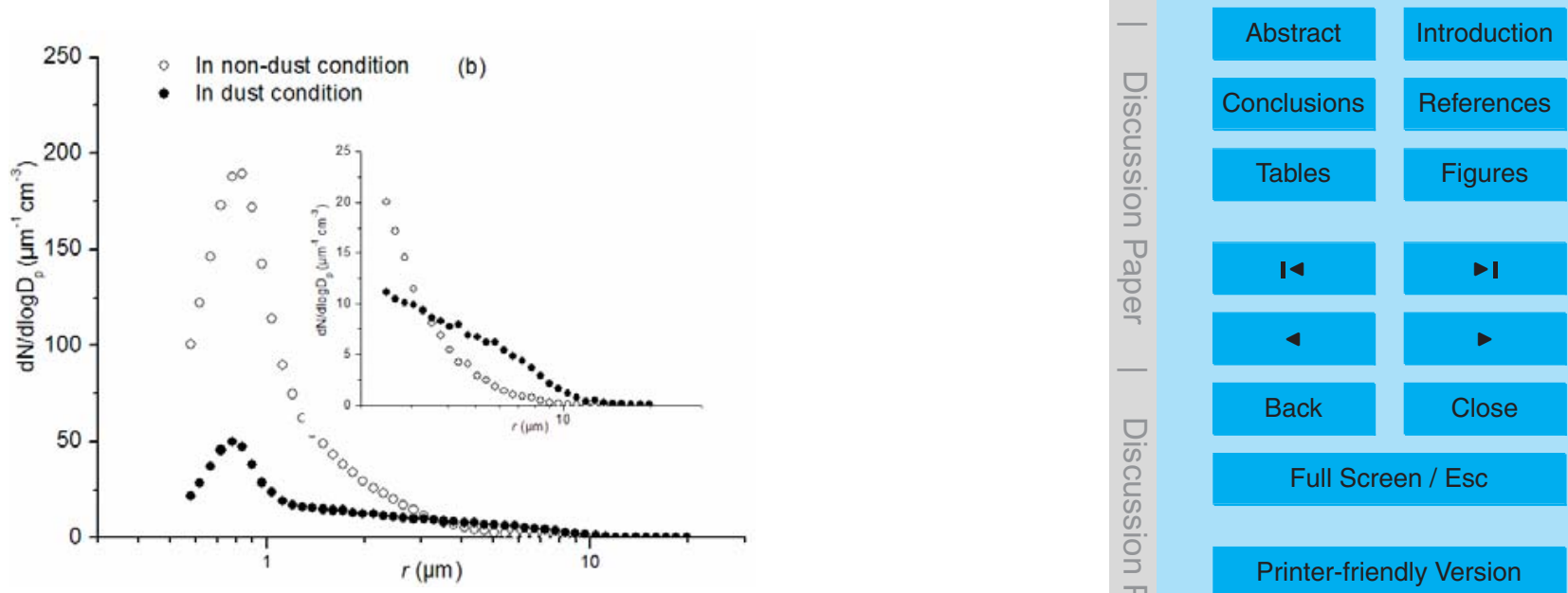

Full Screen / Esc

Printer-friendly Version

Fig. 7. Aerosol size distribution of (a) mass concentration and (b) number concentration at SACOL. 


\section{ACPD}

12, 6113-6143, 2012

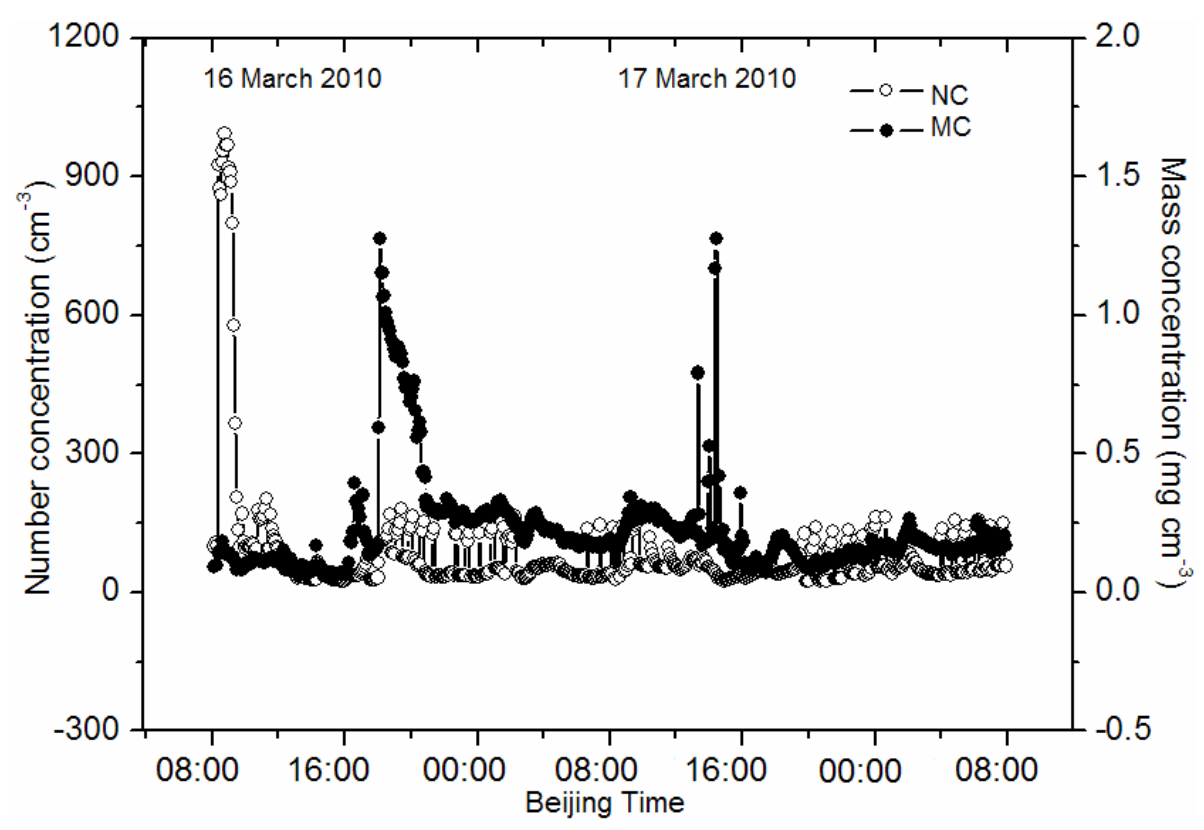

\section{Analysis of the vertical structure and size distribution of dust aerosols}
B. Zhou et al.

Title Page

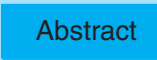

Introduction

Conclusions

References

Tables

Figures

14

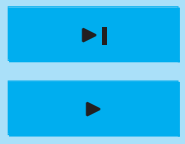

4

Back

Close

Full Screen / Esc mass concentration.

Printer-friendly Version

Interactive Discussion 


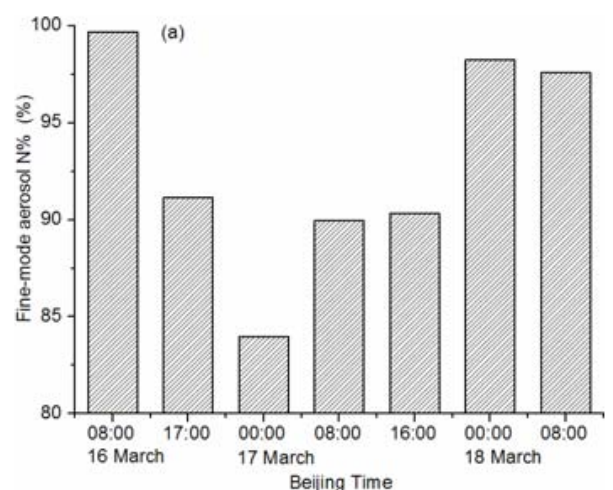

Beijing Time

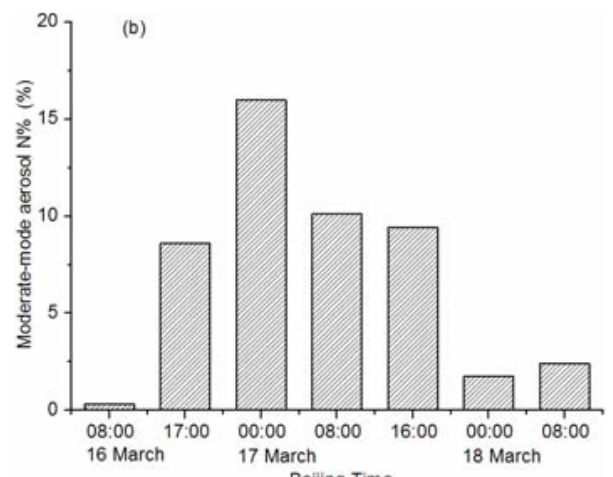

Bejing Time

\section{ACPD}

12, 6113-6143, 2012

\section{Analysis of the vertical structure and size distribution of dust aerosols}

B. Zhou et al.

\section{Title Page}

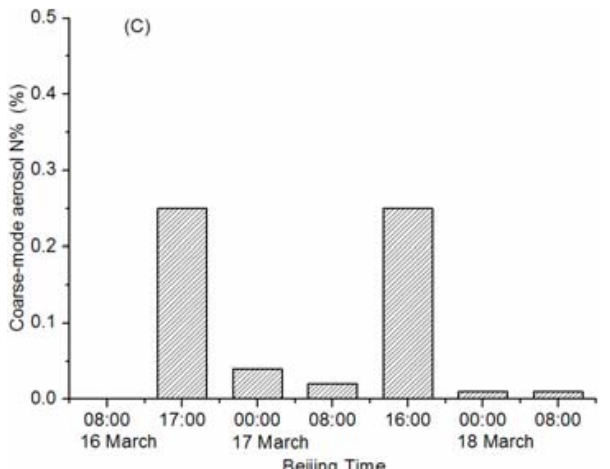

Abstract

Introduction

Conclusions

References

Tables

Figures

14

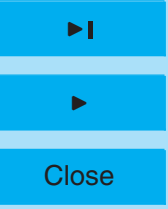

Back

Full Screen / Esc

Printer-friendly Version

Interactive Discussion 

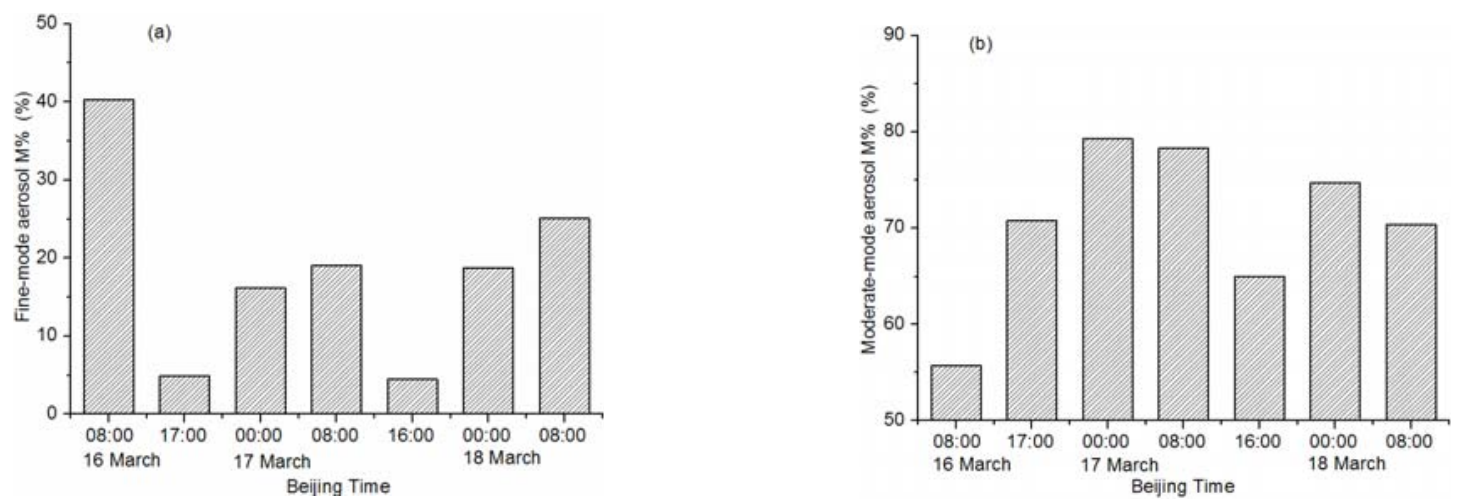

\section{ACPD}

12, 6113-6143, 2012

\section{Analysis of the vertical structure and size distribution of dust aerosols}

B. Zhou et al.

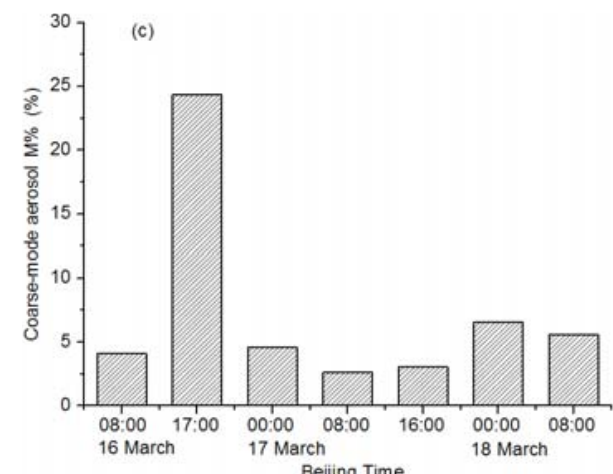

\section{Abstract}

Title Page

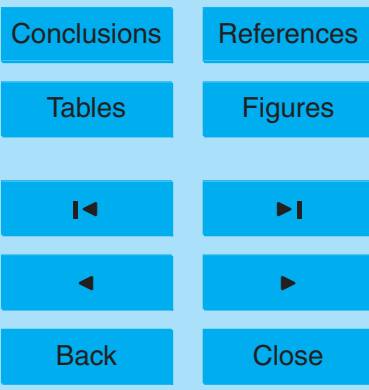

Full Screen / Esc

Fig. 10. Percentages of aerosol mass concentration in total mass concentration within the (a) fine, (b) moderate, and (c) coarse modes.

Printer-friendly Version

Interactive Discussion 


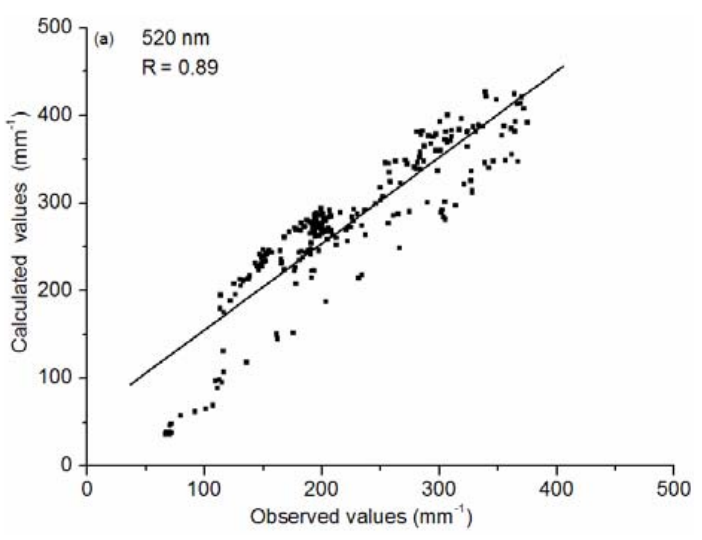

\section{ACPD}

$12,6113-6143,2012$

\section{Analysis of the vertical structure and size distribution of dust aerosols}
B. Zhou et al.

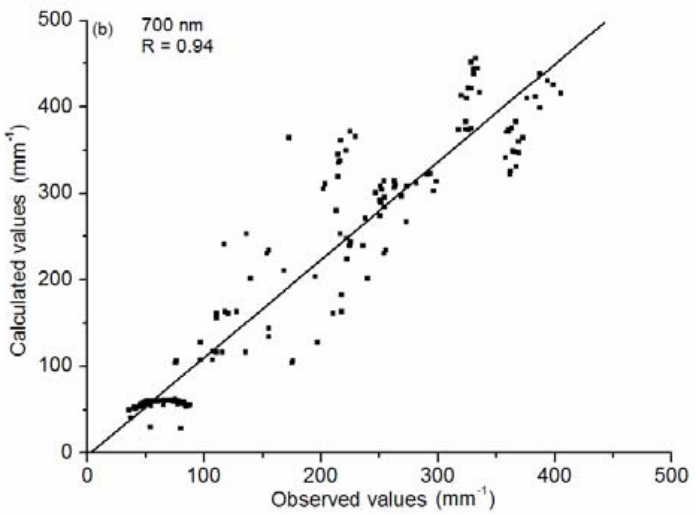

Title Page

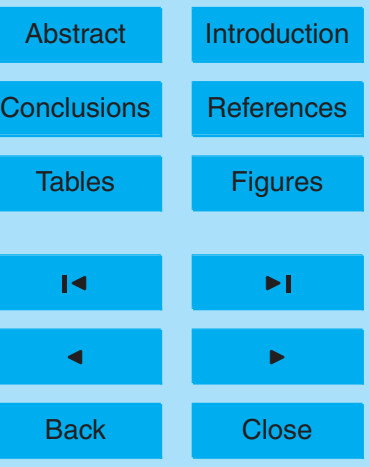

Full Screen / Esc

Fig. 11. Comparison of dust aerosol scattering coefficients at (a) $520 \mathrm{~nm}$ and (b) $700 \mathrm{~nm}$ calculated from Mie theory and observed by the nephelometer.

Printer-friendly Version

Interactive Discussion 


\section{ACPD}

12, 6113-6143, 2012

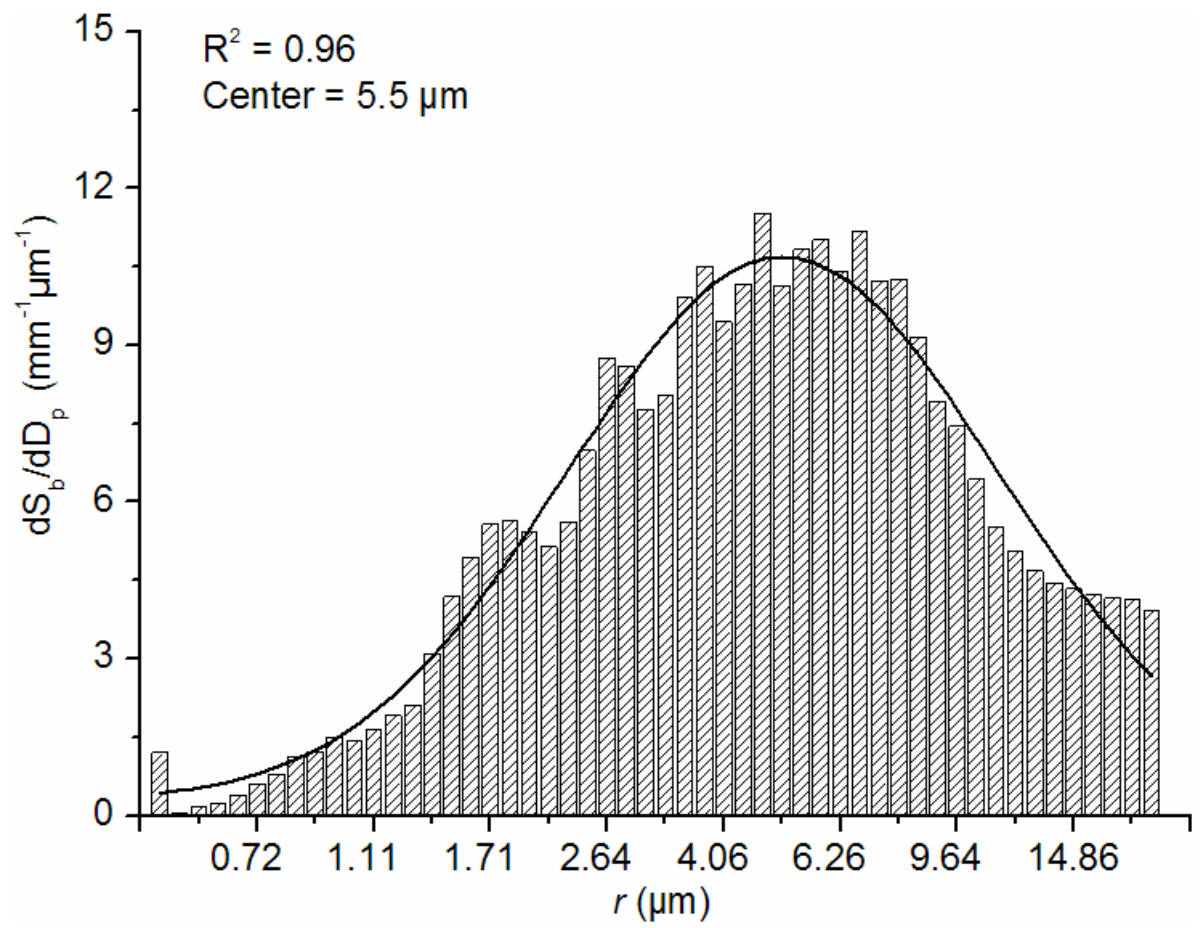

\section{Analysis of the vertical structure and size distribution of dust aerosols}

B. Zhou et al.

Title Page

Abstract

Introduction

Conclusions

References

Tables

Figures

14

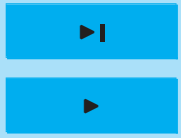

Back

Close

Full Screen / Esc

Fig. 12. Distribution of dust aerosol scattering coefficient against effective diameter.

Printer-friendly Version

Interactive Discussion 


\section{ACPD}

12, 6113-6143, 2012

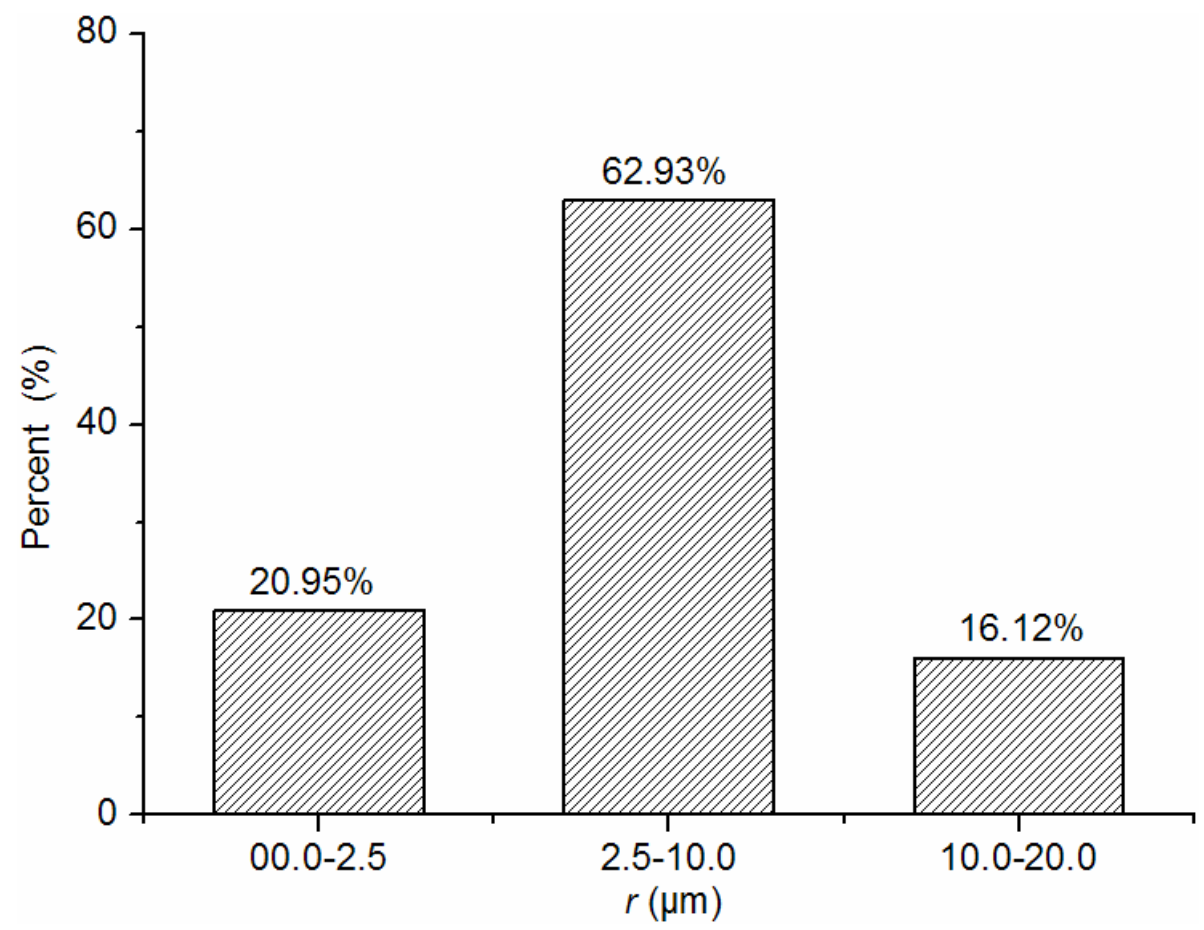

Fig. 13. Contribution percentage of fine-, moderate-, and coarse-mode aerosols to the dust aerosol scattering coefficient.

\section{Analysis of the vertical structure and size distribution of dust aerosols}
B. Zhou et al.

Title Page

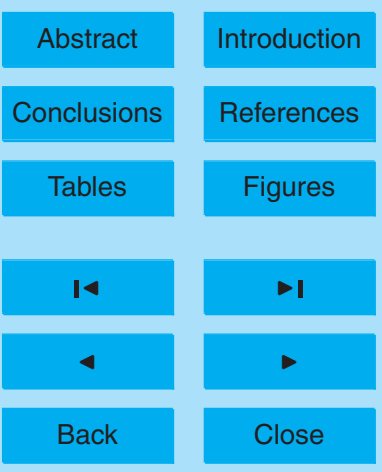

Full Screen / Esc

Printer-friendly Version

Interactive Discussion

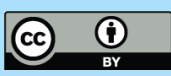

